US Army Corps of Engineers ${ }_{\circledast}$

Engineer Research and

Development Center

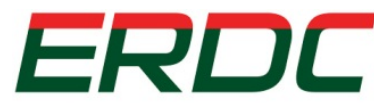

INNOVATIVE SOLUTIONS for a safer, better world

Installation Technology Transition Program (ITTP)

Demonstration of a Rapid Energy Audit Procedure for use with an Army Sustainment Management System (SMS)

Joseph E. Karbarz and Michael N. Grussing

December 2012 
The US Army Engineer Research and Development Center (ERDC) solves the nation's toughest engineering and environmental challenges. ERDC develops innovative solutions in civil and military engineering, geospatial sciences, water resources, and environmental sciences for the Army, the Department of Defense, civilian agencies, and our nation's public good. Find out more at www.erdc.usace.army.mil.

To search for other technical reports published by ERDC, visit the ERDC online library at http://acwc.sdp.sirsi.net/ client/ default. 


\section{Demonstration of a Rapid Energy Audit Procedure for use with an Army Sustainment Management System (SMS)}

Joseph E. Karbarz

Information Technology Laboratory

U.S. Army Engineer Research and Development Center

3909 Halls Ferry Road

Vicksburg, MS 39180-6199

Michael N. Grussing

Construction Engineering Research Laboratory

US Army Engineer Research and Development Center

2902 Newmark Drive

Champaign, IL 61822

Final report

Approved for public release; distribution is unlimited.

Prepared for Office of the Assistant Chief of Staff for Installation Management (ACSIM) Arlington, VA 22202

Under Project FY11-41, "Demonstration of Standardized Energy Audit Procedures with Army Sustainment Management System Life Cycle Metrics for Buildings” 


\section{Abstract}

This report describes the demonstration of a rapid, whole-building energy performance assessment method to efficiently identify buildings for energy-conservation retrofits. The patent-pending process, called First View, can generate an energy signature or model that represents a sample building's energy performance. The only input data required are building type, square footage, monthly average temperatures, and gas and electric consumption for 12 consecutive months. Seven office buildings were assessed at Picatinny Arsenal, NJ. The analysis was performed manually using Microsoft Excel spreadsheet functions to produce summary output, reference charts, graphs, and tables. The First View model performed well across the sample building population. The energy signatures and associated output aligned well with field observations and local knowledge of the buildings under study.

This effort also included a more general effort to the study of total lifecycle cost analysis of facility condition in relation to energy performance. In this connection the authors provide a design for a comprehensive information dashboard report to provide information that could be used to expediently identify facilities that are good candidates for in-depth energy analysis.

DISCLAIMER: The contents of this report are not to be used for advertising, publication, or promotional purposes. Citation of trade names does not constitute an official endorsement or approval of the use of such commercial products. All product names and trademarks cited are the property of their respective owners. The findings of this report are not to be construed as an official Department of the Army position unless so designated by other authorized documents. 


\section{Executive Summary}

In Fiscal Year 2009, US Army energy consumption represented 17\% of total Federal government energy usage. In an effort to respond to Federal policies mandating greater energy efficiency, Army facility managers have increasingly used energy audits as a tool to meet installation energy- and water-conservation goals. These audits are used to develop energy conservation measures that are submitted for consideration in Energy Savings Performance Contracts. Valuable data are being generated by installationlevel energy audits, but it tends to be stovepiped and not readily available for incorporation into total facility life-cycle analysis or aggregation for Army-wide strategic planning purposes.

To address problems arising from stovepiped information flows and processes, recent Department of Defense* and Army† policies call for an integrated approach to the analysis of facility ownership costs over the asset's entire life cycle. However, there is no comprehensive information framework that can properly capture all these costs (recapitalization, energy, water, waste, operation, maintenance, etc.) for integrated life-cycle management at the facility, complex, or component level. Such a framework would make it possible to integrate facility life-cycle data from strategic planning through the operational phase.

This project demonstrates an energy analysis technique, based on an algorithm called First View (New Buildings Institute [NBI], Vancouver, WA), which has the potential to interoperate with Army Sustainment Management Systems (SMS) and facilitate better integration of energy consumption data into Army facility life-cycle information systems.

\section{Benefit}

The US Army developed the BUILDER SMS to help Department of Public Works facility managers develop better forecasts of maintenance, repair, and recapitalization requirements. SMS technology provides consistent and meaningful metrics based on engineering expertise, and provide man-

\footnotetext{
* Department of Defense Sustainable Buildings Policy, 25 OCT 2010, Deputy Undersecretary of Defense (Installations and Environment).

† Sustainable Design and Development Policy Update (Environmental and Energy Performance), 27 OCT 2010, Assistant Secretary of the Army (Installations, Energy, and Environment).
} 
agement decision support from high-level budgetary planning through local project completion. The BUILDER SMS Condition Index is used to project a schedule for repairing or renewing individual components and optimizing it to provide the most favorable return on investment (ROI).

BUILDER's automated capabilities currently account for recapitalization savings by comparing the extended building service life gained through repairs with the expected design life for a replacement facility. BUILDER can be used to evaluate operational ROI, including energy usage, for different maintenance or replacement scenarios, but the SMS cannot calculate these saving automatically; it requires manual data entry and user judgment. The predictive power of BUILDER could be extended by adding the automated capability to calculate operational costs under different scenarios and incorporate them into the ROI. This capability would provide planners and facility managers with a more accurate reflection of the Army's total cost of ownership. Additionally, the automation of these calculations would make the process considerably more time-efficient.

\section{Cost analysis}

This work produced a set of best practices for identifying buildings that are suitable candidates for in-depth energy audits and for establishing metrics for energy performance cost calculations. That information is then used within the BUILDER SMS to include potential energy cost savings in the consideration of building component replacement activities. This new integrated capability could produce guidance for incorporating wholebuilding energy and other sustainability requirements into the facility manager's decision-making process. This guidance will help managers make the best budgetary decisions about prioritizing rehabilitation with respect to condition degradation, functional obsolescence, energy costs, reliability, maintenance costs, and expected effects on the building occupants and mission. Once this capability has been developed for energy performance, similar principles can be applied to develop metrics, cost models, and calculations for water use, waste production, carbon footprint, and operations and maintenance costs.

\section{Implementation}

The First View algorithm demonstrated in this work was executed manually. Building property data were gathered, including weather, gas, electric, and occupancy data; processed using Microsoft Excel; and interpreted us- 
ing the metrics, charts, and graphs output by the First View algorithm. This manual process requires close inspection of data. Gas and electric usage, along with several critical building properties, comprise the key parameters processed by the algorithm. The resulting data values generally appeared to be reasonable. However, upon closer inspection, errors were evident. Corrections involved an iterative process and required engineering interpretation of energy and condition-assessment output.

The BUILDER platform could serve as a suitable framework for data stores and automation for integrated implementation of First View. However, data availability and quality will continue to be a central issue in the development of a fully integrated and automated capability.

\section{Recommendation}

The results of this demonstration are promising and can serve as a basis for developing a standardized energy audit procedure that integrates well with asset life-cycle management. It is recommended that the First View algorithm be automated, and that functionality for BUILDER be developed to (1) filter candidate facilities for in-depth energy audits, (2) define an algorithm to improve investment timing of repair-versus-replace life-cycle decisions, and (3) provide the reports and dashboard display screens needed in the BUILDER application.

First View intellectual property belongs to New Buildings Institute and Energy Resource Management Inc., so an agreement on intellectual property and licensing must be completed before further development can be pursued. 


\section{Contents}

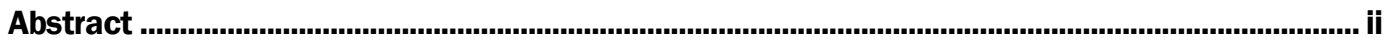

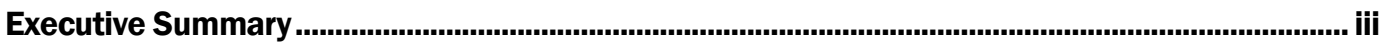

Figures and Tables.....................................................................................................................................

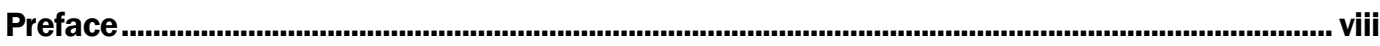

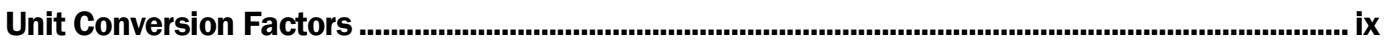

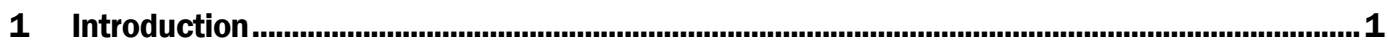

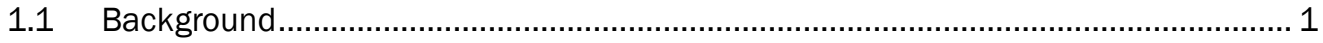

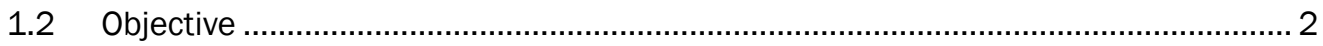

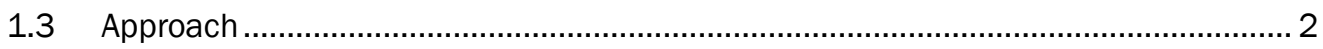

1.4 Mode of technology transfer ......................................................................... 3

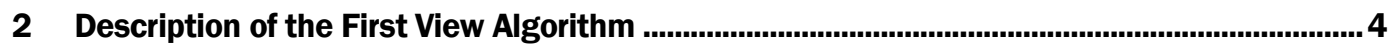

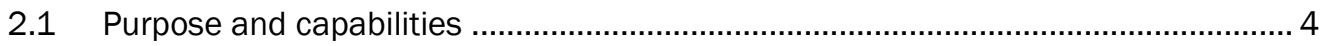

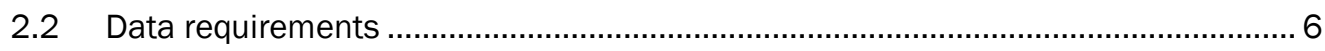

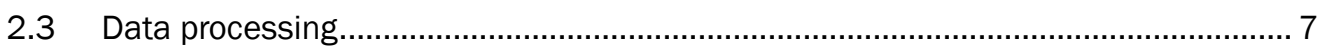

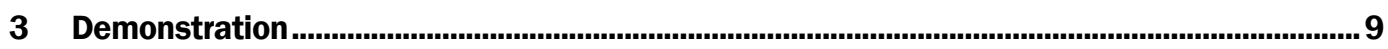

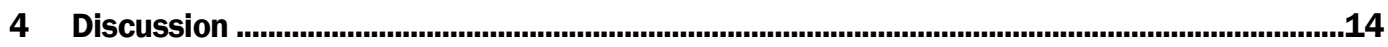

4.1 Considerations for implementation ................................................................ 14

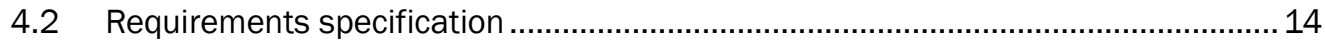

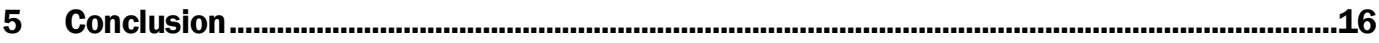

References ..............................................................................................................................................17

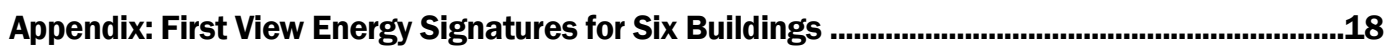

Report Documentation Page 


\section{Figures and Tables}

\section{Figures}

Figure 1. Sample energy signature produced by First View................................................................ 5

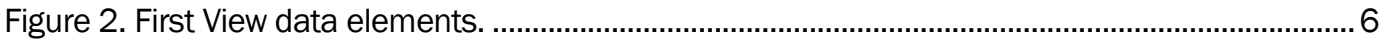

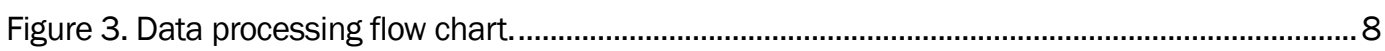

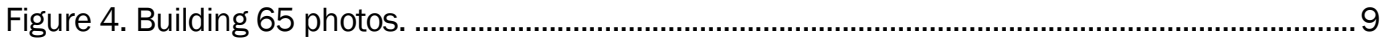

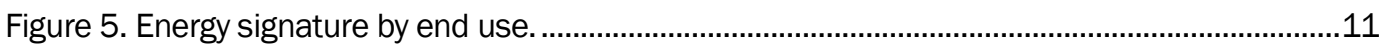

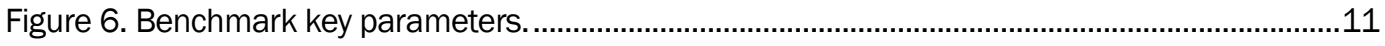

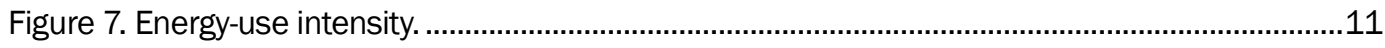

Figure 8. Energy signature reference comparison. ........................................................................12

Figure 9. Energy signature with metered energy use .........................................................................13

\section{Tables}

Table 1. Building 65 energy signature observations..........................................................................10

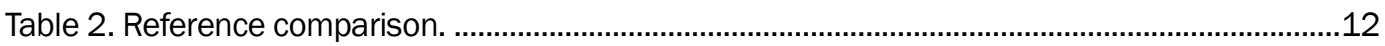




\section{Preface}

This study was conducted for the US Army Assistant Chief of Staff for Installation Management (ACSIM) under Installation Technology Transition Program (ITTP) Project FY11-41, "Demonstration of Standardized Energy Audit Procedures with Army Sustainment Management System Life Cycle Metrics for Buildings." The ITTP Program Manager was Debbie J. Lawrence, CEERD-CV-T, and the Technical Monitor was Philip R. Columbus, DAIM-ODF.

The work was performed by the Engineering Processes Branch ( $\mathrm{CF}-\mathrm{N})$ of the Facilities Division (CF), US Army Engineer Research and Development Center - Construction Engineering Research Laboratory (ERDC-CERL). At the time of publication, Donald K. Hicks was Chief, CEERD-CF-N; L. Michael Golish was Chief, CEERD-CF; and Martin J . Savoie, CEERD-CVZT, was the Technical Director for Installations. The Deputy Director of ERDC-CERL was Dr. Kirankumar Topudurti and the Director was Dr. Ilker Adiguzel.

COL Kevin J . Wilson was the Commander of ERDC, and Dr. J effery P. Holland was the Director. 


\section{Unit Conversion Factors}

\begin{tabular}{|l|c|l|}
\hline Multiply & By & To Obtain \\
\hline British thermal units (International Table) & $1,055.056$ & joules \\
\hline cubic feet & 0.02831685 & cubic meters \\
\hline degrees Fahrenheit & $($ F-32)/1.8 & degrees Celsius \\
\hline feet & 0.3048 & meters \\
\hline gallons (U.S. liquid) & 3.785412 E-03 & cubic meters \\
\hline inches & 0.0254 & meters \\
\hline pounds (force) per square inch & 6.894757 & kilopascals \\
\hline pounds (mass) & 0.45359237 & kilograms \\
\hline square feet & 0.09290304 & square meters \\
\hline
\end{tabular}




\section{Introduction}

\subsection{Background}

In Fiscal Year 2009, US Army energy consumption represented 17\% of total Federal government energy usage. In an effort to respond to Federal policies mandating greater energy efficiency, Army facility managers have increasingly used energy audits as a tool to meet installation energy- and water-conservation goals. These audits are used to develop energy conservation measures that are submitted for consideration in Energy Savings Performance Contracts.

Army facility managers use the BUILDER ${ }^{\circledR}$ Sustainment Management System for decision support, creating SRM and operations and maintenance (O\&M) work plans and projects that are cost effective based on the asset's condition and remaining service life. However, facility energy consumption and performance have historically been the responsibility of energy assessment experts who provide Level 1, 2, or 3 energy audits according to the practices of the American Association of Heating, Refrigerating, and Air-Conditioning Engineers (ASHRAE). Consequently, energy performance data tend to remain in an energy management stovepipe and therefore are not readily available for incorporation into total facility lifecycle analysis or aggregation for Army-wide strategic planning purposes.

To address the general problem of stovepiped information flows and processes, recent Department of Defense ${ }^{1}$ and $\mathrm{Army}^{2}$ policies call for an integrated approach to the analysis of facility ownership costs over the asset's entire life cycle. However, there is currently no comprehensive information framework that can properly capture all these costs (recapitalization, energy, water, waste, operation, maintenance, etc.) for integrated life-cycle management at the facility, complex, or component level. Such a framework would make it possible to integrate facility life-cycle data from the strategic planning phase all the way through to the operational level.

\footnotetext{
1 Department of Defense Sustainable Buildings Policy, 25 OCT 2010, Deputy Undersecretary of Defense (Installations and Environment).

2 Sustainable Design and Development Policy Update (Environmental and Energy Performance), 27 OCT 2010, Assistant Secretary of the Army (Installations, Energy, and Environment).
} 
This Installation Technology Transition Program (ITTP) project demonstrates a rapid energy-analysis technique, based on an algorithm called First View (New Buildings Institute [NBI], Vancouver, WA), that has the potential to interoperate with existing building condition-assessment tools and facilitate future integration of energy consumption data into Army facility life-cycle information systems. The First View algorithm, when initialized only with daily weather data and the monthly energy bill information required for calculating an Energy Star rating, can be used to generate a model that represents the energy-performance signature of a building. The only required input data are building type, square footage, monthly average temperatures, and gas and electric consumption for 12 consecutive months.

This demonstration addresses the issue of energy consumption from an integrated perspective that includes both energy efficiency and building condition for use in developing a total facility life-cycle cost of ownership. The authors explore potential enhancements to the BUILDER SMS using the NBI First View Analog Building Model and describe the concept for a BUILDER information "dashboard" that displays energy-related data within a matrix of current information presented to the user.

\subsection{Objective}

The objective of this work was to assess the utility of the NBI First View algorithm for rapidly producing a building energy-consumption analysis and output that that is compatible with the BUILDER SMS.

\subsection{Approach}

The demonstration of this technology encompassed the following tasks:

1. Identify energy-related variables.

2. Collect data sets.

3. Synchronize data (data collection across monthly cycle).

4. Run solution engine.

5. Chart the data.

6. Interpret results.

7. Integrate energy savings results with BUILDER. 


\subsection{Mode of technology transfer}

The results of this demonstration can be used in developmental work to integrate the First View Analog Building Model into a future release of the BUILDER SMS. The methods proposed in this project could provide the installation energy manager and Department of Public Works personnel the tools and techniques to assess a large building inventory at the least cost. Through integration into BUILDER, this capability could provide real-time facility information for readiness reporting and SRM planning support.

First View intellectual property belongs to New Buildings Institute and Energy Resource Management Inc. Intellectual property and licensing agreements must be concluded before advanced development and implementation within BUILDER can be pursued. 


\section{Description of the First View Algorithm}

\subsection{Purpose and capabilities}

The First View model estimates the values for a selection of metrics to produce an energy signature of the subject building being assessed. It estimates the performance of a whole building based on its physics, using engineering equations for characteristics such as heat transfer, fluid mechanics, and thermodynamics. An analysis using First View can provide effective feedback from actual building operations and promote a deeper level of building performance review. Using this approach could help Department of Public Works personnel identify significant and previously unknown energy-performance deficiencies.

The Energy Star Portfolio Manager ${ }^{1}$ is currently the most widely accepted energy benchmark methodology. The rating it generates provides no hard information about the building or its physics, but only a comparative ranking among all buildings in the same category. An Energy Star value of 70, for example, essentially says that the building's energy performance is better than 70 percent of all others buildings rated in the same category. No empirical information can be derived from the rating. Also, the Energy Star rating is based on national averages of source energy, using a multiplier of 3.4 regardless of energy type or cost. For example, hydroelectric, nuclear, and coal-generated electricity is treated equally (i.e., a $60 \%$ energy loss from the source), and the baseline data were derived from the 2003 Commercial Buildings Energy Consumption survey. For all these reasons, the Energy Star rating is of limited use.

First View operates on the basis of actual gas and electric meter data. Importantly, its output produces an energy signature based on real-world building physics for the purpose of identifying actionable targets for improving performance. First View encompasses a whole-building perspective that can reveal broad categories of conservation measures not previously known to building managers. The model provides a whole-building energy analysis suitable for rapid energy-performance studies. In engineering terms, the First View model works by aggregating and summing various parameters to produce useful, actionable forms of output. For ex-

\footnotetext{
${ }^{1}$ http://www.energystar.gov/index.cfm?c=evaluate_performance.bus_portfoliomanager.
} 
ample, First View combines heat transfer conductivity and infiltration into a parameter called the "Aggregate UA," which is a measure of thermal characteristics of a building envelope such as wall $R$ value, glazing $U$, or ventilation.

First View checks energy billing data and provides an initial indication of performance to help identify building characteristics that are likely to offer major energy-saving opportunities. This initial assessment does not generate detailed diagnostics or specific recommendations, but identifies broad categories for focusing an energy-performance analysis. This preliminary evaluation technique is well suited for application to large facility inventories.

Automating the algorithm would create a scalable approach that could provide measured performance interpretations. From monthly energy bills, which are readily available, the analyst using First View can prioritize buildings for study to find out how a building is performing, what is driving that result, and how to act on the results. First View feedback is reportable for several operational domains: Design/Construction addresses mechanical systems and structural functions; Tenants and Occupants addresses managing unnecessary loads; and Owner/ Operators addresses settings and controls.

First View's data interpretations are used to produce the building's total energy signature, which is illustrated in Figure 1.

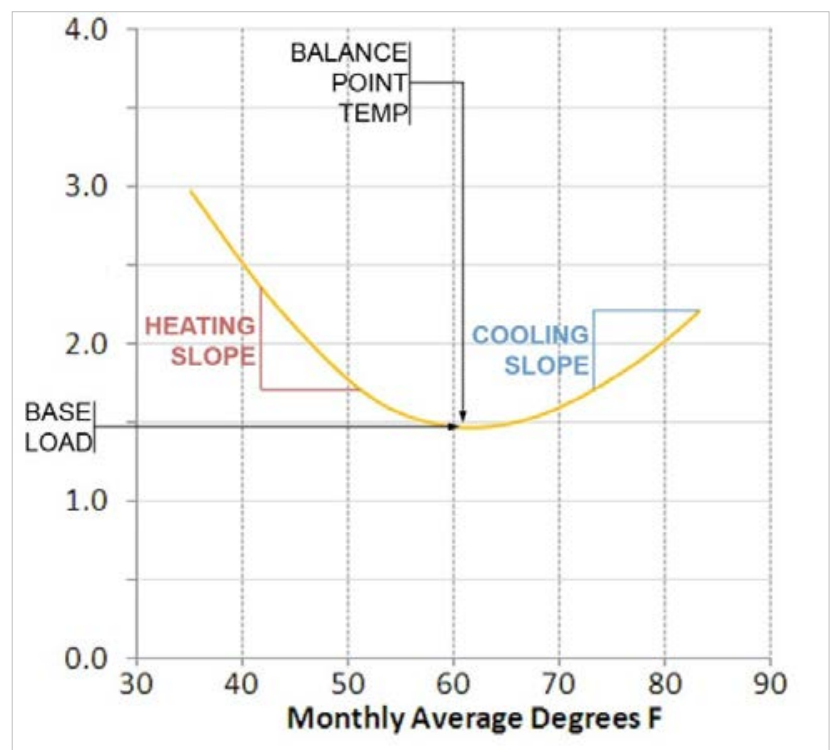

Figure 1. Sample energy signature produced by First View. 
Four key performance-related characteristics comprise the energy signature: baseload, heating slope, cooling slope, and balance point. The base load represents internal loads, tenants' schedules, and the operations of systems and controls. The heating slope, cooling slope, and balance point relate largely to building physics, not the activities of the occupants.

First View uses a general reference model for comparison to help evaluate individual building energy signatures. This reference model suggests the best possible performance that could be expected for a standard office building with good overall energy efficiency, sound energy conservation design, and good operational practices.

\subsection{Data requirements}

Twelve consecutive months of gas and electric data are required along with location-specific monthly average temperature, use type, and building square footage. Figure 2 illustrates the data elements, including certain optional properties (upper right in figure) that can help to improve the analysis.

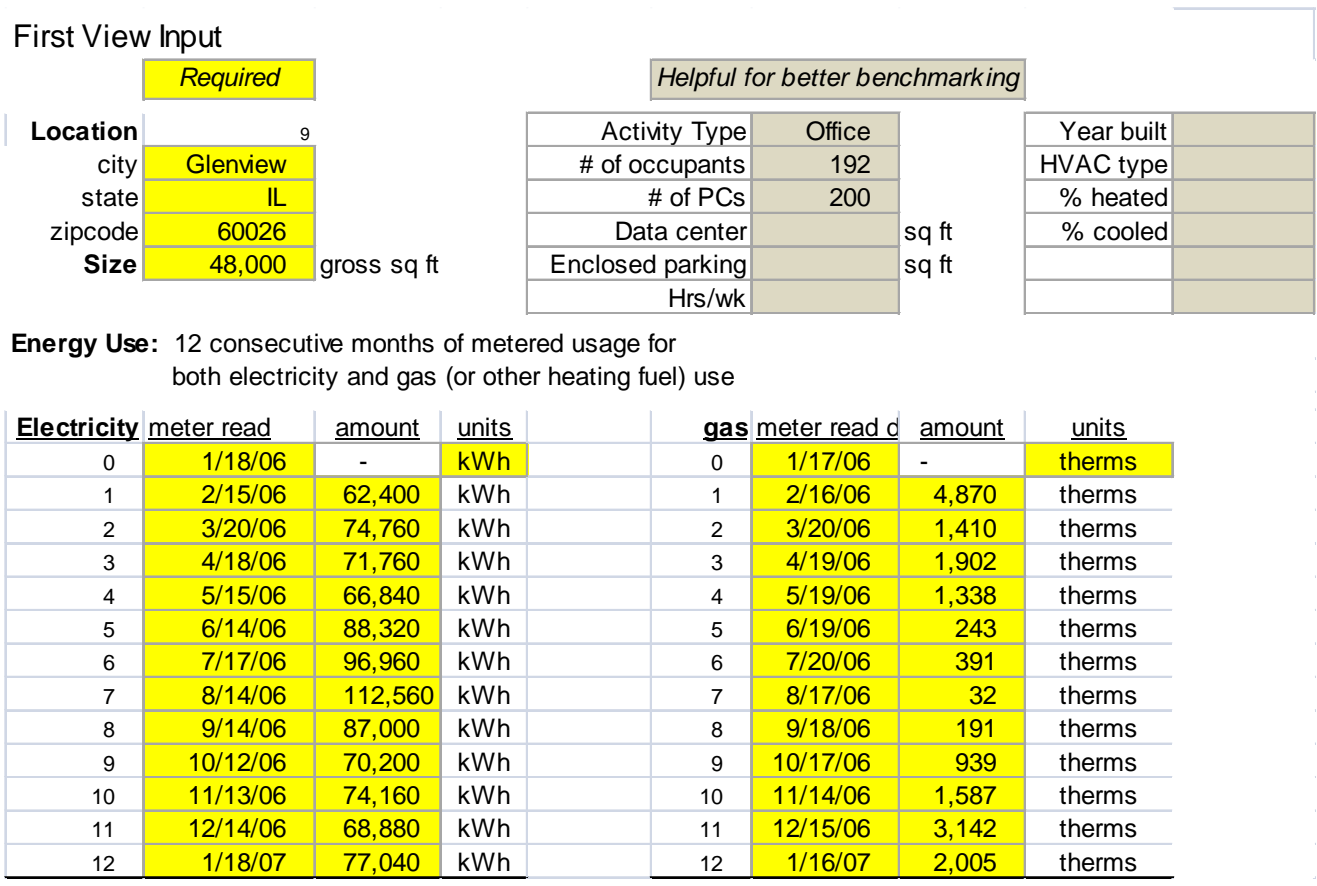

Figure 2. First View data elements.

As installations install meters at individual facilities to track local gas, electricity, and water usage, it creates the data source required by First View for analyzing a building's current state. That data, when combined 
with life-cycle condition data about the facility available in BUILDER, could provide an initial framework for identifying energy- and conditionbased SRM improvements.

One long-term outcome of using such a technology should be to reduce the cost of Army facility energy audits due to improved focus on highprobability projects. Also, an automated implementation of First View could help to direct resources to buildings with the poorest energy performance and/ or potential for high returns on SRM investment. Energysavings goals could be achieved sooner due to earlier and more comprehensive identification of SRM projects that include an energy component. A standardized energy-assessment model would provide a means to determine the effect of different energy-efficiency measures, including the cost-effectiveness of system upgrades and building retrofits.

\subsection{Data processing}

A general data-processing life cycle is needed to generate a building energy signature. The First View solution engine computes a best-fit regression model based on input data to create a baseline equation that represents historical building energy use. Internal calculations of the data yield a model with physical parameters that result in a similar energy usage profile. The final derived values are triggered by control indicators such as the $\mathrm{R}$-square value of the statistical regression.

First View uses a six-step data processing procedure:

1. identify all variables

2. collect data sets

3. synchronize data (data collection across billing cycle)

4. run solution engine

5. chart the data

6. interpret results.

A more detailed view of the data processing flow is shown in Figure 3. 
- Validate Data

- Reset Calculation Array

- Iterate Gradient Increment

- Find Maximum Iteration

- Calculate to Max $\mathrm{R}^{2}$

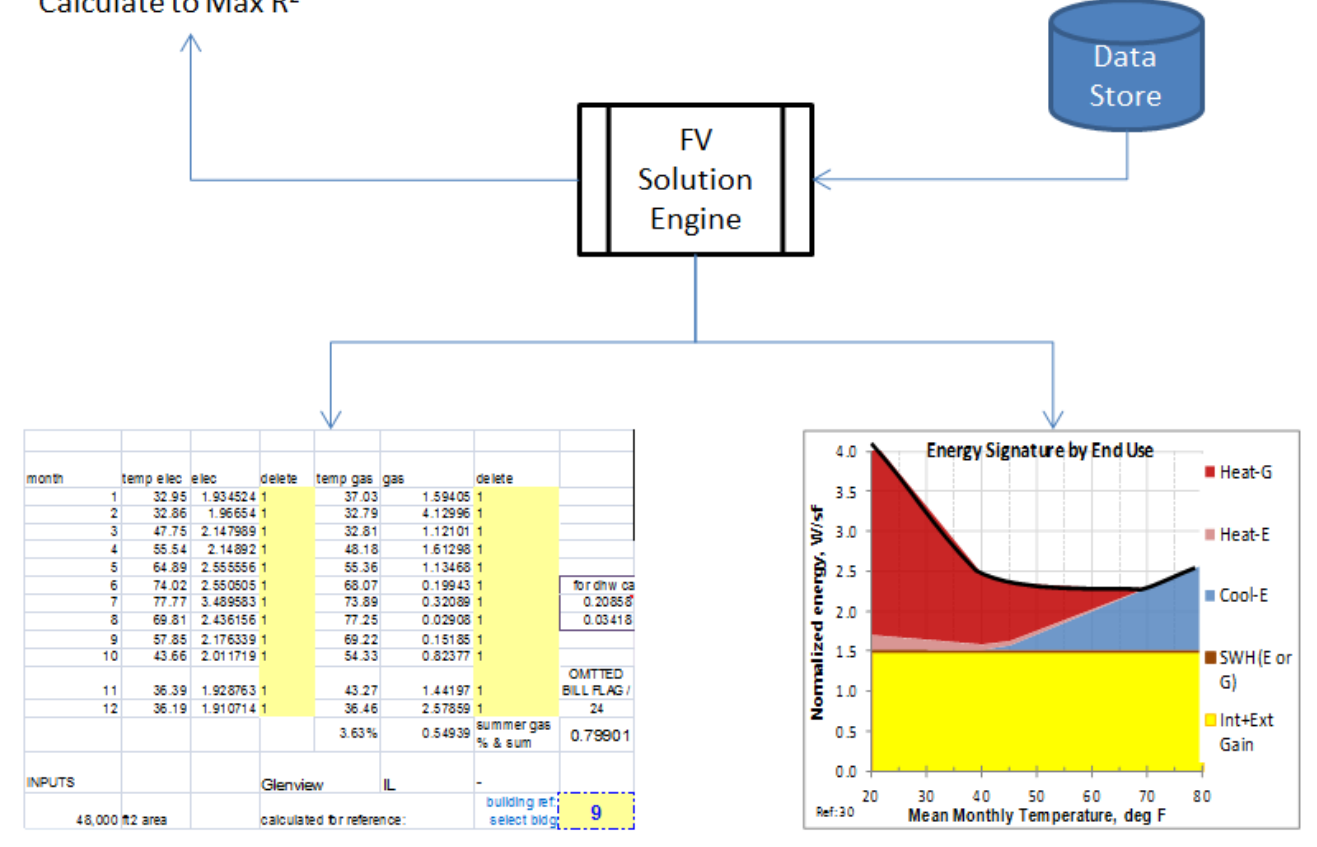

Figure 3. Data processing flow chart. 


\section{Demonstration}

Seven buildings at Picatinny Arsenal, NJ , were analyzed using the First View algorithm. This chapter presents the results for Building 65. Results for the other six buildings are included in Appendix A. The focus here is Building 65 (Figure 4) because of the availability of a recent retrocommissioning report for it that provides the opportunity to confirm First View output and test it for relevance with the observed building condition.
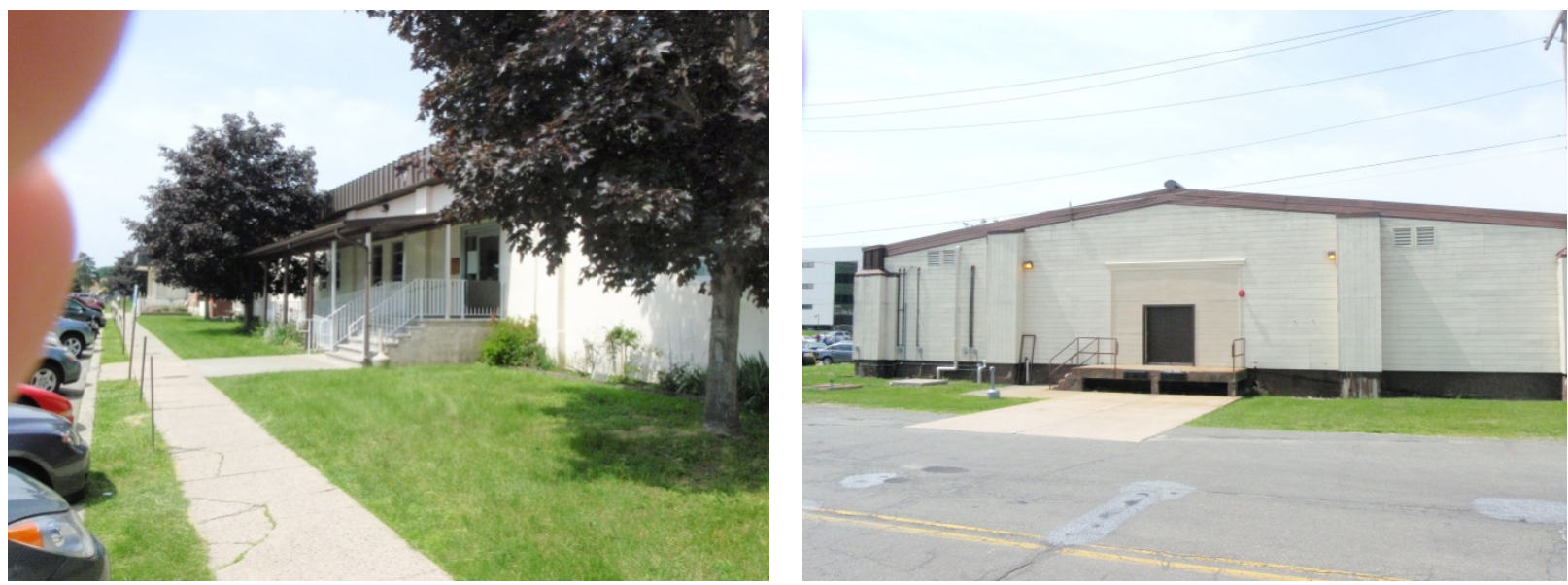

Figure 4. Building 65 photos.

In the case of Building 65 ,First View flagged one primary area for further investigation: very steep increases in heating as the outside temperature decreases. This condition typically suggests excessive ventilation and possible problems with insulation or heat distribution.

A DPW site review of the facility found characteristics consistent with the First View output:

- very high overhead space with an uninsulated ceiling and roof

- windows sometimes open in winter to moderate excessive heat from baseboard radiators

- some fans operating around the clock

- possible negative impact of boiler location, outside the main building, on heat-distribution efficiency.

In addition, First View identified a potential solar gain, indicating more cooling and less heating than suggested by the other parameters. A site re- 
view confirmed problems with building orientation that lead to excess heat gains at the building's southeast corner and reports of discomfort by occupants.

Building 65 was originally constructed as a 65,000 sq ft warehouse. It is now used as an open-plan, one-story office building. According to the retro-commissioning report, the building has a history of severe thermal comfort problems, much of it attributed to steam baseboard elements and steam coils in the air handling units. Poor mechanical system zoning also contributes to the problem.

Table 1 summarizes the seven key parameters of the building model output for Building 65.

Table 1. Building 65 energy signature observations.

\begin{tabular}{|l|l|}
\hline & Signature Observation \\
\hline Electric base load & Low electric base load \\
\hline Overall gas use & Very high gas heat use \\
\hline $\begin{array}{l}\text { Heating impact of shell and } \\
\text { ventilation }\end{array}$ & High temperature sensitivity of shell/ventilation \\
\hline Gas base load & No excess gas use apparent from circulation/standby loss or reheat \\
\hline Cooling efficiency & Very good cooling efficiency \\
\hline Reheat & No apparent excessive reheat \\
\hline HVAC fan/pump use & No apparent excessive energy use by systems fans/pumps \\
\hline Data consistency & Orderly monthly performance \\
\hline
\end{tabular}

The energy signature and automated observations from First View support the retro-commissioning study conclusions and the field observations of Picatinny DPW personnel. Facility managers have received many complaints from Building 65 occupants about excessive heating. Note that in the energy signature, the model identifies heating shell and ventilation problems.

First View analysis output consists of a series of charts and graphic to aid in the interpretation of results. Figure 5 through Figure 9 and Table 2 show the proposed elements of a dashboard display for the BUILDER SMS. 


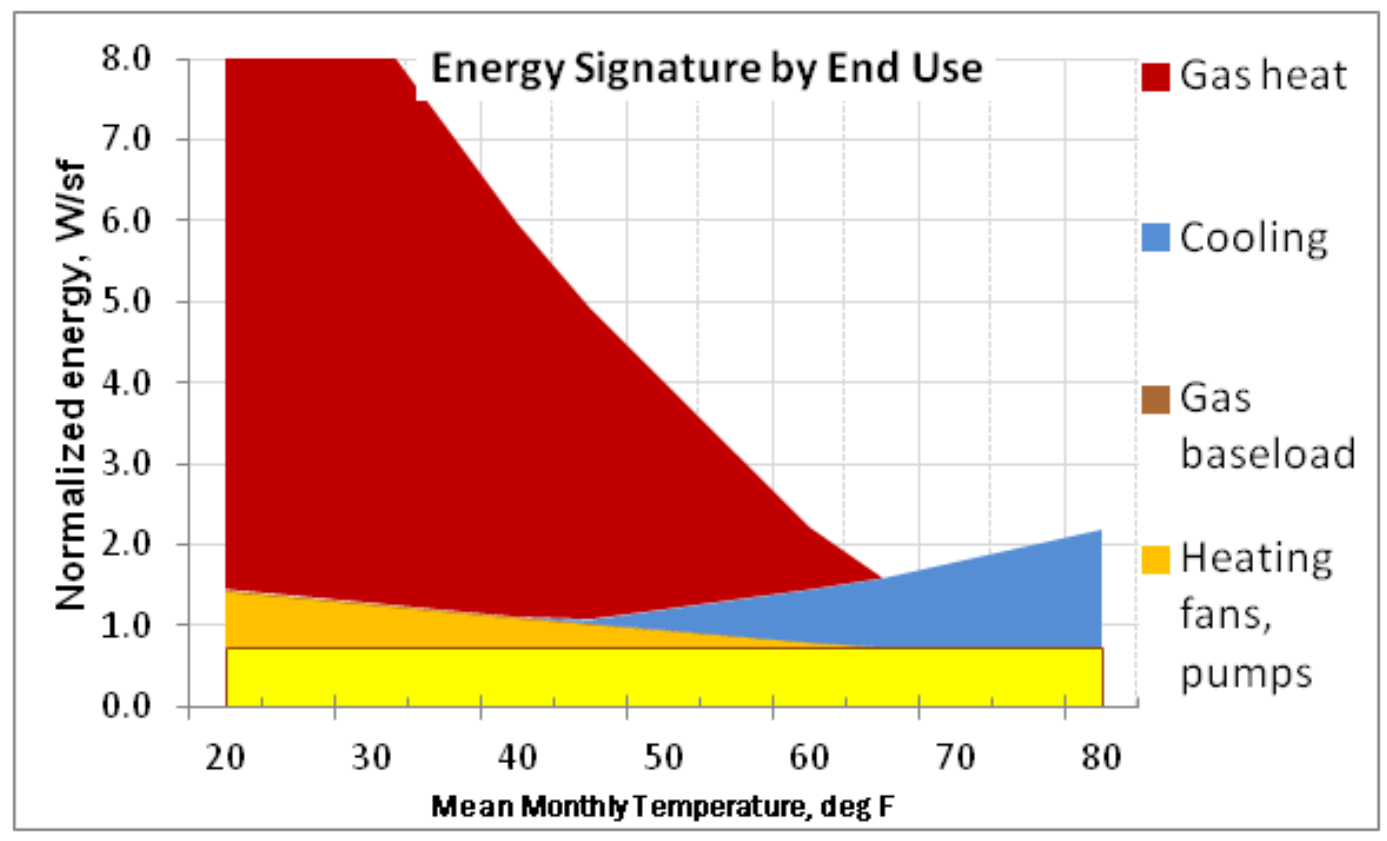

Figure 5 . Energy signature by end use.

\section{Benchmark Values by Performance Area}

Key Indicators from Signature Parameters

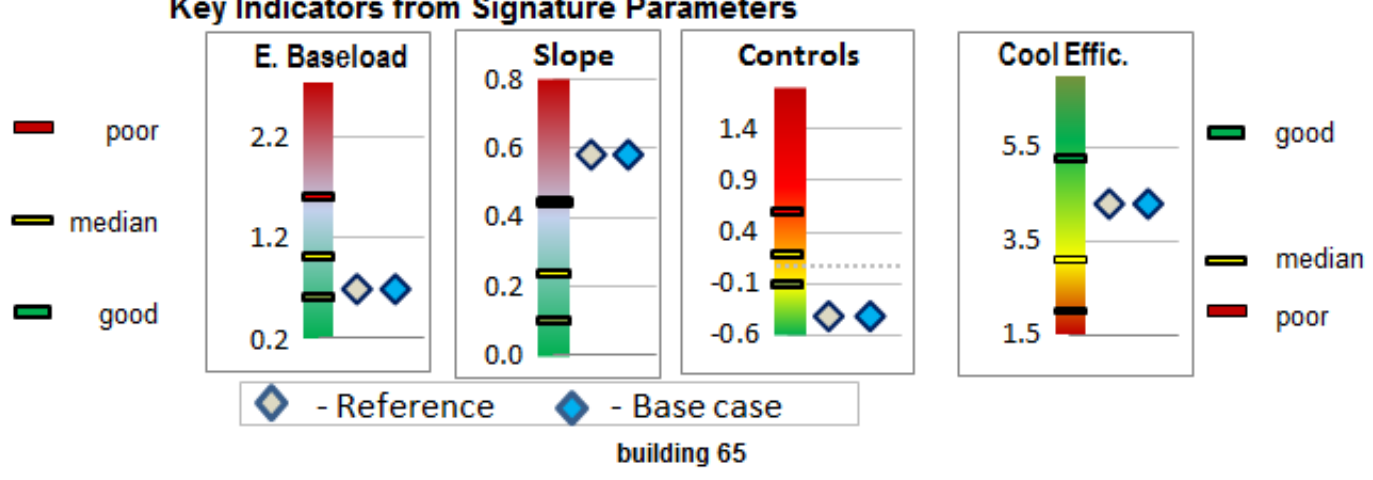

Figure 6. Benchmark key parameters.

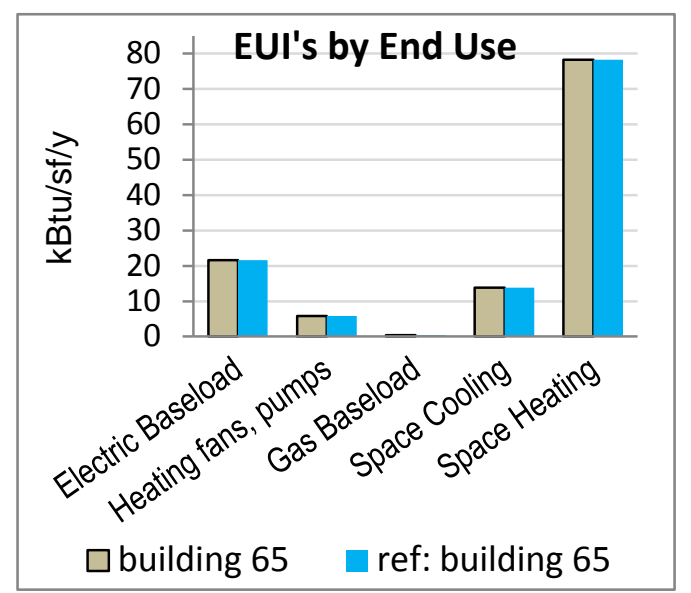

Figure 7. Energy-use intensity. 
Table 2. Reference comparison.

\begin{tabular}{lll|ll} 
& \multicolumn{2}{l}{ Building 65 } & ref: Building 65 \\
\cline { 2 - 5 } & $\mathrm{kBtu} / \mathrm{sf} / \mathbf{y}$ & $\begin{array}{l}\text { \% of } \\
\text { total }\end{array}$ & kBtu/sf/y & \% of total \\
\hline Electric Base load & 21.6 & $18.0 \%$ & 21.6 & $18.0 \%$ \\
Heating fans, pumps & 5.9 & $4.9 \%$ & 5.9 & $4.9 \%$ \\
Gas Base load & 0.5 & $0.4 \%$ & 0.5 & $0.4 \%$ \\
Space Cooling & 13.9 & $11.5 \%$ & 13.9 & $11.5 \%$ \\
Space Heating & $\underline{78.3}$ & $\underline{65.2 \%}$ & $\underline{78.3}$ & $\underline{65.2 \%}$ \\
Total & 120.1 & $100.0 \%$ & 120.1 & $100.0 \%$
\end{tabular}

This project within the range of comparable projects

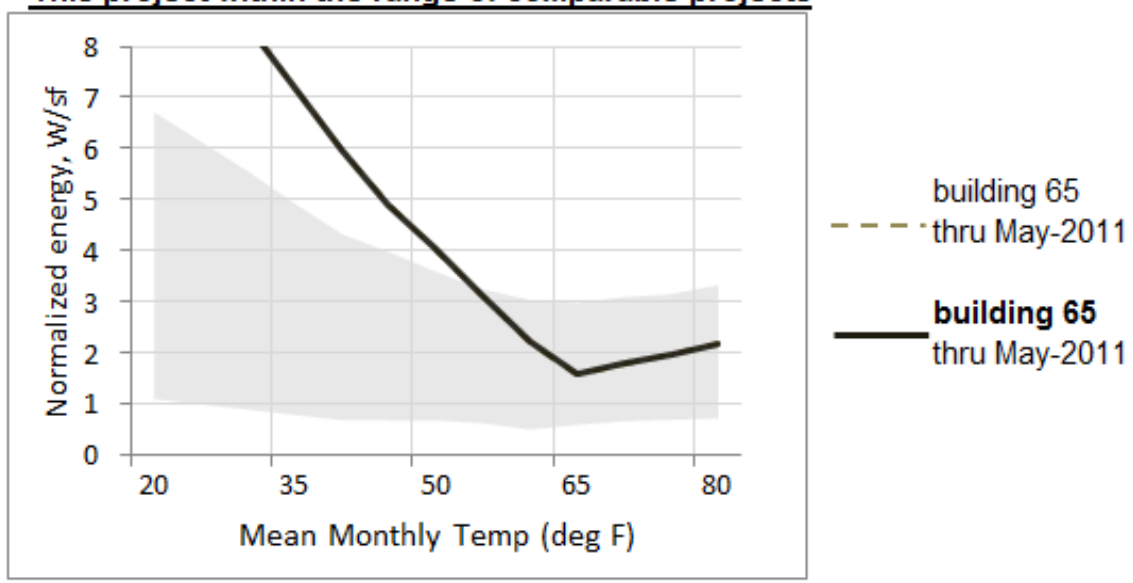

Figure 8. Energy signature reference comparison. 


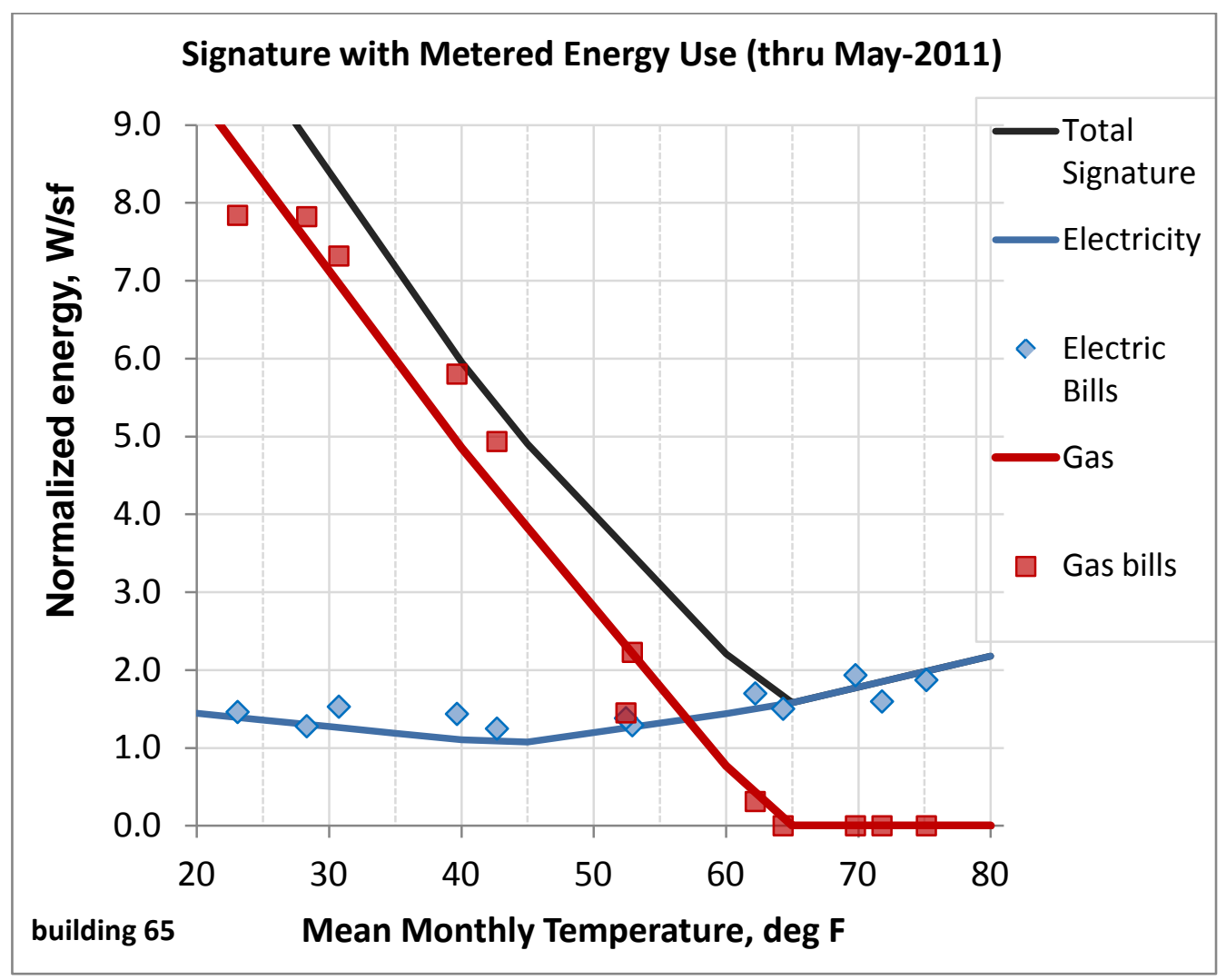

Figure 9. Energy signature with metered energy use. 


\section{Discussion}

\subsection{Considerations for implementation}

The First View algorithm was used to profile seven office buildings, collect gas and electric data for them buildings, and analyzed the results. The technology has potential, and could enhance the Army SMS portfolio. That would involve integrating First View into the SMS framework.

The First View procedures have matured within the context of manual processing in a one-time application, but developing the tool into an automated rapid-assessment procedure would require structured analysis, software design, and programming. The high-level requirements for a development path are discussed below.

\subsection{Requirements specification}

The long-term development objective would be to define a fully functional, rapid, and automated energy benchmarking application that can provide and display facility energy performance data within an SMS "energy dashboard." The results must persist in a database and be readily available in the form of a BUILDER dashboard screen or report. The solution must be modular and fully integrated into the SMS framework. It also must be created using state-of-the-art software development practices. The initial specification follows:

1. Document and codify the core computations for the First View algorithm

2. Define a workflow sequence for data processing

3. Identify the necessary data storage elements to persistent data

4. Identify and codify data conversion methods

5. Process KwHours $\rightarrow \mathrm{Wt} / \mathrm{SF}$

6. Process Therms $\rightarrow \mathrm{Wt} / \mathrm{SF}$

7. Define the following database tables or provide a data source table for:

a. Electric and gas usage data

b. Reference facilities by use type

c. Computation ouput values

d. Energy Star building parameters

e. First View lookup tables 
8. Create the following plots/ graphs:

a. Monthly gas use plot

b. Monthly electric use plot

c. End Use plot

d. Signature review graph

e. Energy by end use plot

f. Benchmark values by key indictors

g. Normalized energy vs. reference building

9. Identify and leverage a reliable weather data source, preferably via a no-cost web service or managed data source.

10. Create a .NET 4.0 First View data processor engine using VB

11. Create a unit test harness for API validation

12. Create a Flags and Messages data table

13. Ensure that all necessary components of the solution are encapsulated into one DLL and database.

14. Develop in Microsoft SQL Server 2008 and Visual Studio 2010 .NET 4.0

15. Provide an automated iteration procedure with automatic stop point intelligence

16. Process an R-square data element for best fit/ iteration counter

17. Provide an iteration counter mechanism

18. Provide a start, reset, stop, clear mechanism

19. Allow for the processing of $X$ number of buildings per run

20. Create an administrator application front end for desktop processing

21. Expose the API to the web

22. Host the solution for R\&D and testing purposes

23. Create a collection of reference buildings

24. Define, store and manage at least a couple use types

25. Include an Energy Star rating and EUI based on required data elements to process these metrics

26. Create reports to capture necessary knowledge for decision making. 


\section{Conclusion}

The First View building energy modeling algorithm was demonstrated in an energy-performance study of seven buildings located at Picatinny Arsenal, NJ . The algorithm was implemented as a Microsoft Excel spreadsheet. For each building, electric and gas billing data were input to the spreadsheet as well as other information, including building location, size, space utilization, number of occupants, and type of heat-distribution system. Execution of the algorithm produced a set of output reports, including a building-specific energy signature, plots, charts, and tables, suitable for implementation as BUILDER SMS dashboard displays. Engineering interpretation was applied to identify problems or areas needing improvement to meet SRM requirements.

With further development, an automated First View module could be coded and implemented within the BUILDER SMS to leverage energy-related building information already captured in installation-specific BUILDER applications. Technology transfer would involve establishing intellectual property and licensing agreements with the developer of First View, New Buildings Institute (NBI), Vancouver, WA. 


\section{References}

[DOE] Department of Energy. 2009. Commercial Reference Buildings. Version 1.2_4.0. http:// www1.eere.energy.gov/buildings/commercial_initiative/reference_buildi ngs.html

Doty, Steve, and Wayne C. Turner. 2010. Energy Management Handbook, 7th Ed. The Fairmont Press.

[EPA] Environmental Protection Agency. 2010. “ENERGY STAR Portfolio Manager Overview."

http://www.energystar.gov/index.cfm?c=evaluate_performance.bus_portfoliomanager

[FEMP] Federal Energy Management Program. 2010. Final Report, Picatinny Arsenal Buildings 1, 12, 65, \& 176 Retro-Commissioning Study.

Kissock, J . K., J . S. Haberl and D.E. Claridge. 2003. “Inverse modeling toolkit: numerical algorithms." ASHRAE Transactions, 109 Part 2.

Kissock, J . K., and S. Mulqueen. 2008. "Targeting energy efficiency in commercial buildings using advanced billing analysis." In Proceedings of ACEEE Summer Study on Energy Efficiency in Buildings, 2-159, 2-170.

Turner, C., and H. Reichmuth. 2009. “Using Measured Whole-Building Performance for Green Building Program Evaluation." In Proceedings of the 2009 Energy Program Evaluation Conference, Portland, OR, pp 751 - 763. 


\section{Appendix: First View Energy Signatures for Six Buildings}

This appendix documents the First View results for six of the seven buildings from the Picatinny Arsenal study sample: Buildings 7, 60, 67, 92, 94, and 3323.

\section{Building 7}

First View results for Building 7 indicate very high heat pattern similar to Building 65. Suspiciously high cooling efficiency that may indicate an alternate cooling source. First View signal "confused" by the erratic electricity and high gas use. There may be irregular equipment use or plug loads from month to month? A check for very low heating efficiency is recommended.

\begin{tabular}{ll}
\hline & Signature Observations \\
Electric base load & Typical electric base load \\
Overall gas use & Very high gas heat use \\
Heating impact of shell and & High temperature sensitivity of shell/ventilation \\
ventilation & \\
Gas base load & No excess gas use apparent from circulation/standby loss or \\
& reheat \\
Cooling efficiency & Very good cooling efficiency \\
Reheat & No apparent excessive reheat \\
HVAC fan/pump use & No apparent excessive energy use by systems fans/pumps \\
Data consistency & Irregular monthly data. Possible erratic controls, data \\
& inaccuracies, or irregular occupant loads
\end{tabular}




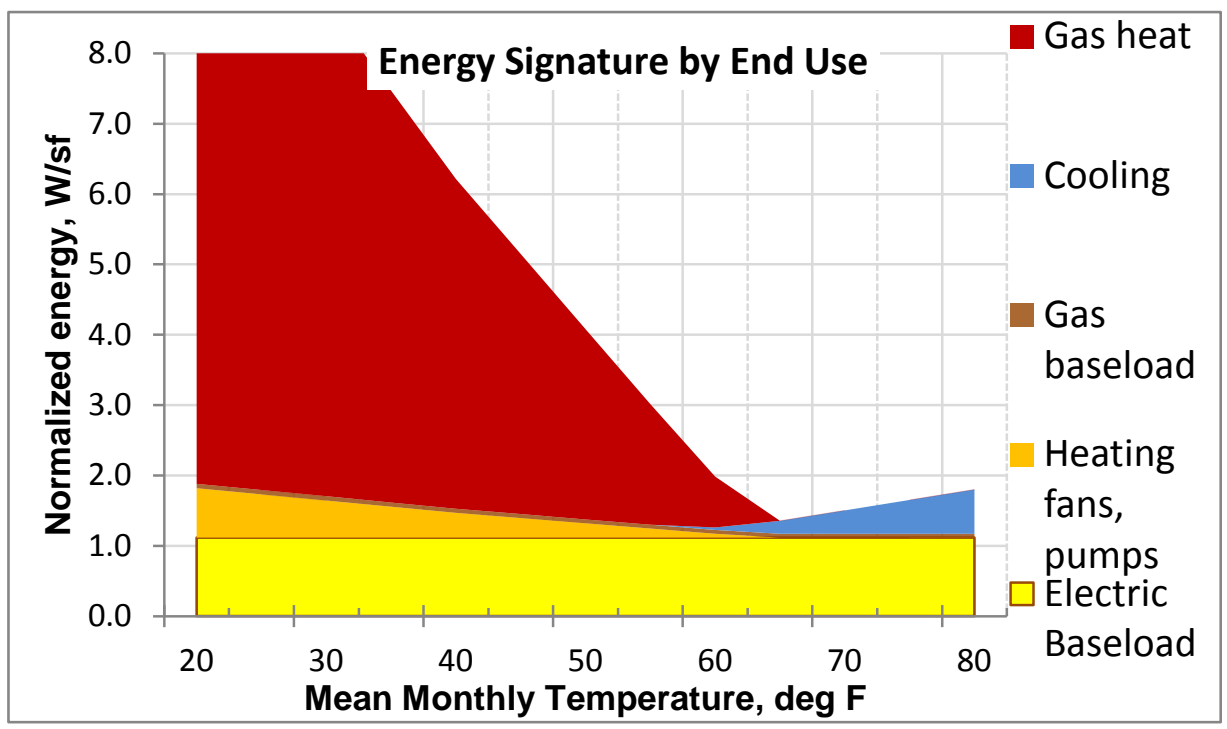

Benchmark Values by Performance Area

Key Indicators from Signature Parameters
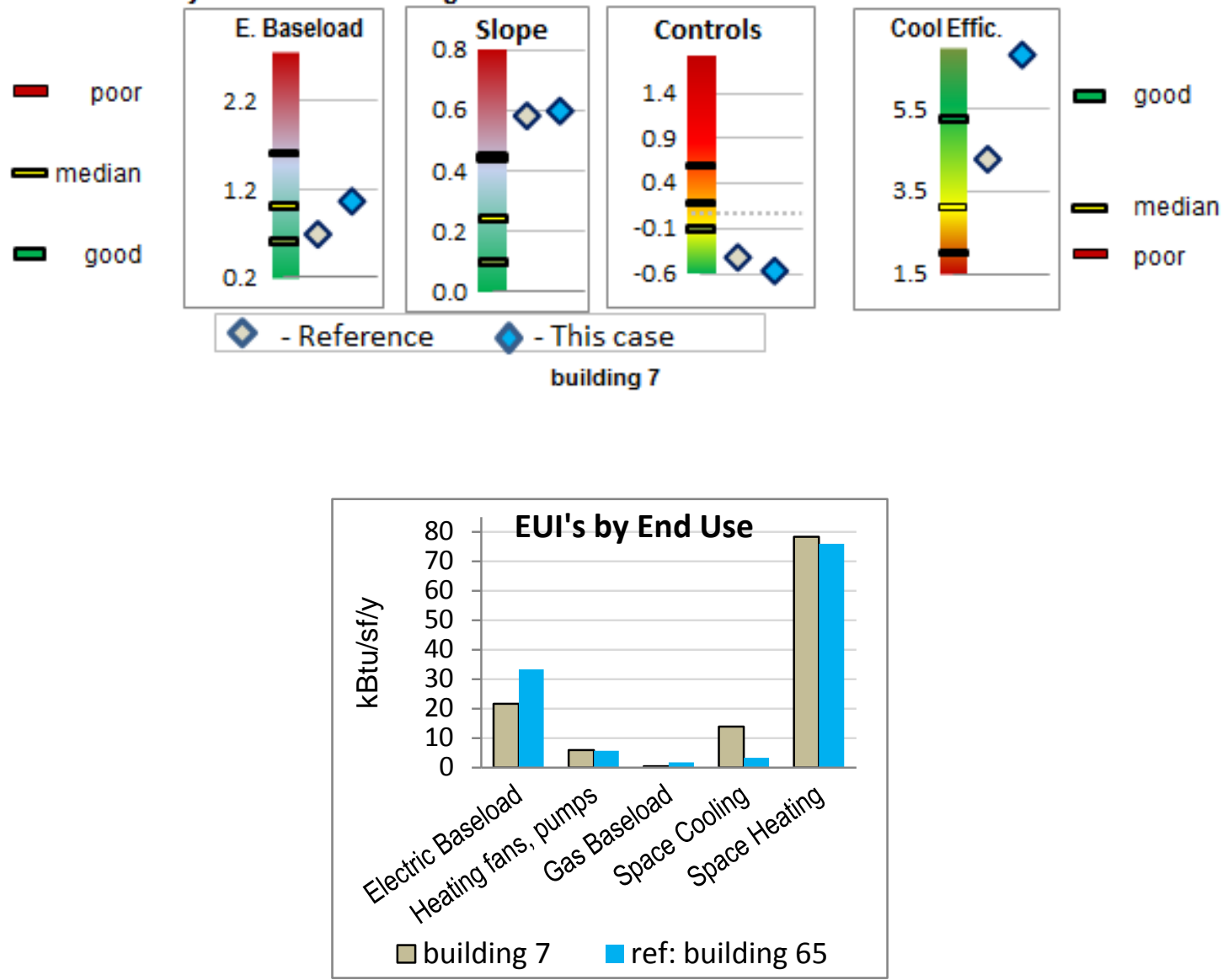


\begin{tabular}{lll|ll} 
& \multicolumn{2}{l|}{ ref: Building 65 } & building 7 \\
\cline { 2 - 5 } & kBtu/sf/y & \% of total & kBtu/sf/y & \% of total \\
\hline Electric Base load & 21.6 & $18.0 \%$ & 33.4 & $27.8 \%$ \\
Heating fans, pumps & 5.9 & $4.9 \%$ & 5.7 & $4.7 \%$ \\
Gas Base load & 0.5 & $0.4 \%$ & 1.8 & $1.5 \%$ \\
Space Cooling & 13.9 & $11.5 \%$ & 3.3 & $2.7 \%$ \\
Space Heating & 78.3 & $65.2 \%$ & 76.0 & $63.3 \%$ \\
Total & 120.1 & $100.0 \%$ & 120.1 & $100.0 \%$
\end{tabular}

This project within the range of comparable projects
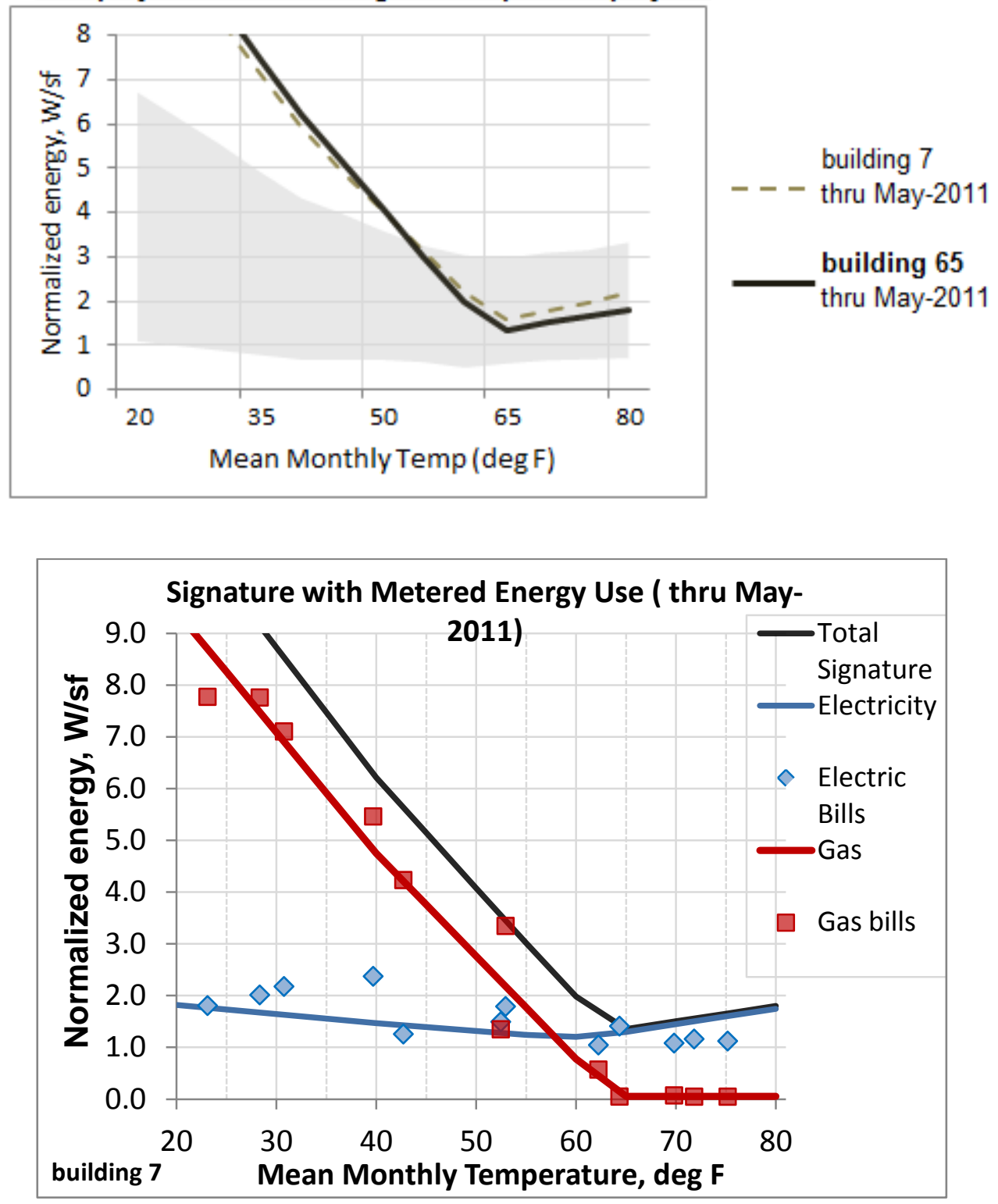


\section{Building 60}

As with Buildings 65 and 7, Building 60 First View analyses shows an extremely high heat slope, again likely very high ventilation. Also, extremely low electric base load, which in conjunction with the high heat, probably implies the standard First View split between plug load/lights and heating pumps/fans is overstated.

Looking back at the raw billing points, the previous winter had even higher heat use.

\begin{tabular}{ll}
\hline & Signature Observations \\
Electric base load & Low electric base load \\
Overall gas use & Very high gas heat use \\
Heating impact of shell and & High temperature sensitivity of shell/ventilation \\
ventilation & \\
Gas base load & No excess gas use apparent from circulation/standby loss or reheat \\
Cooling efficiency & Very good cooling efficiency \\
Reheat & No apparent excessive reheat \\
HVAC fan/pump use & No apparent excessive energy use by systems fans/pumps \\
Data consistency & Orderly monthly performance \\
\hline
\end{tabular}

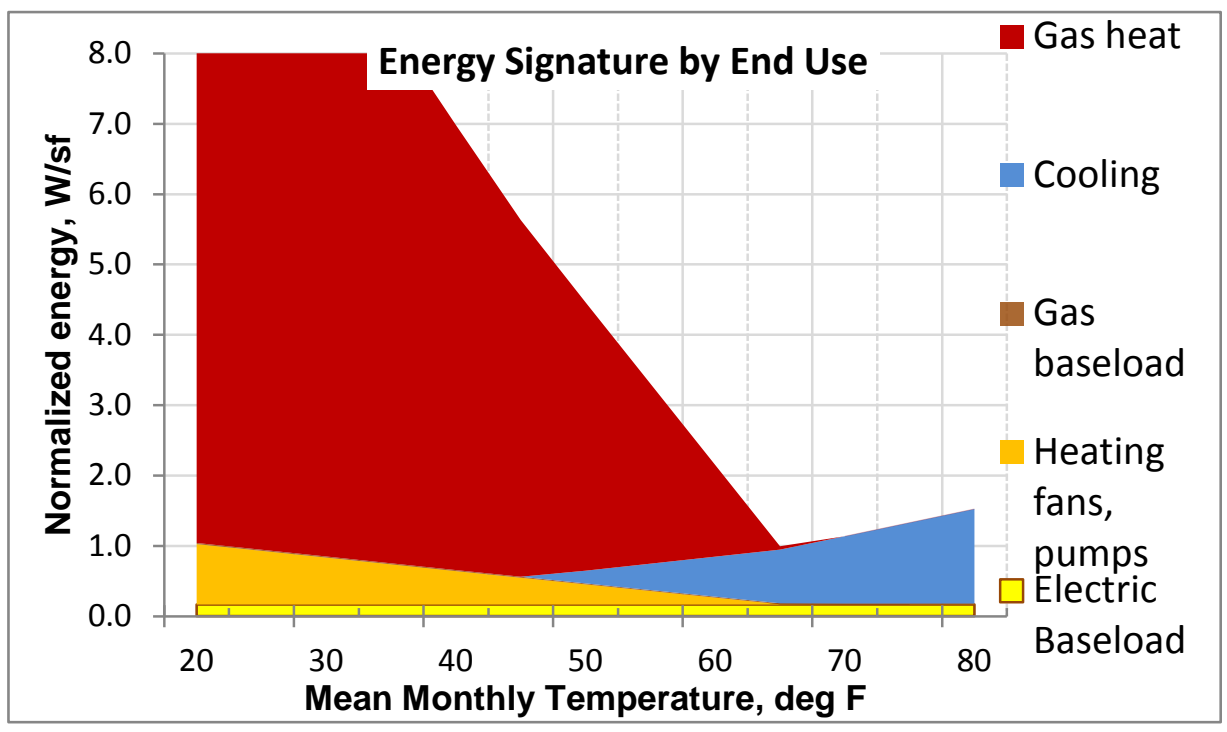


Benchmark Values by Performance Area

Key Indicators from Signature Parameters
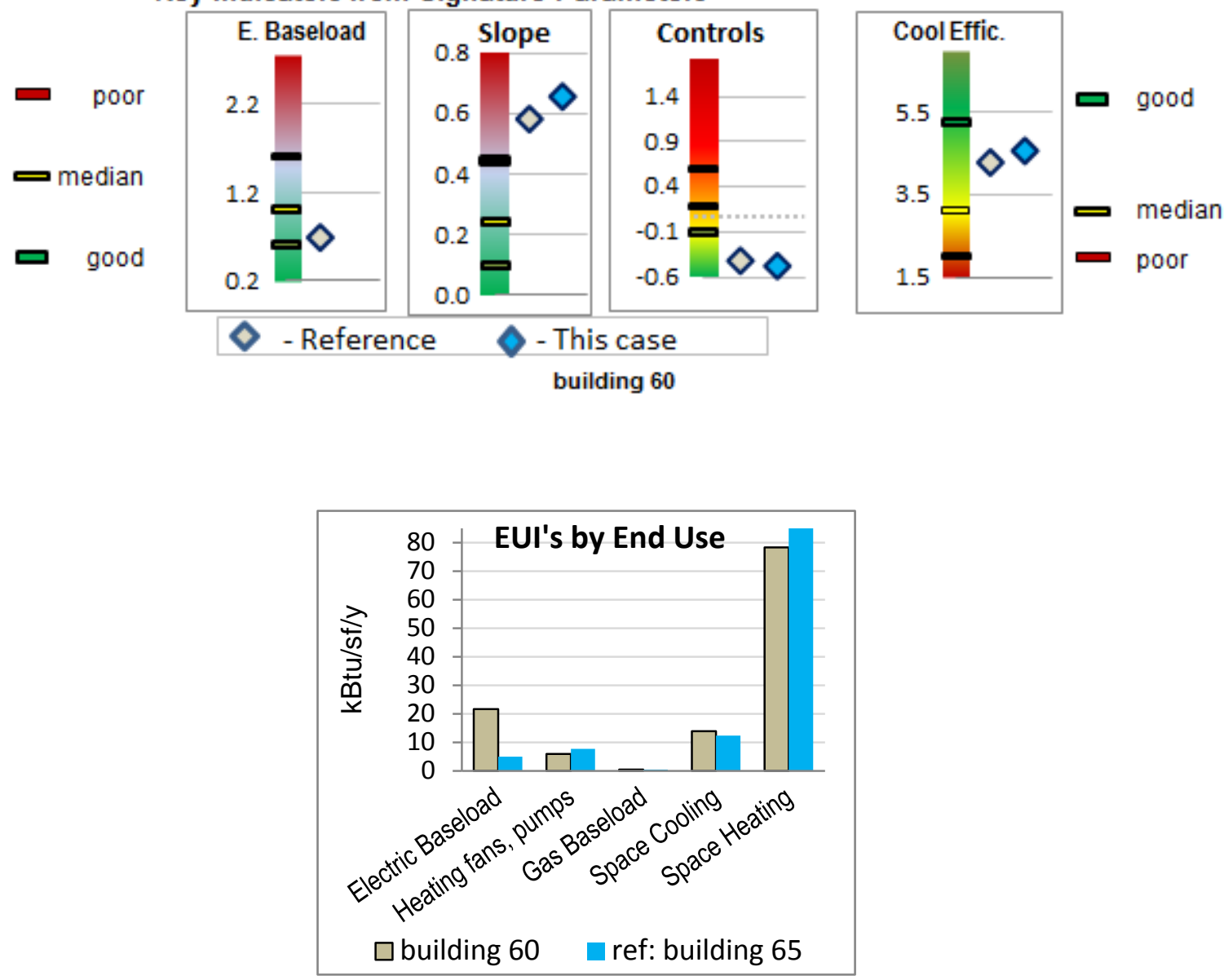

\begin{tabular}{lll|ll} 
& \multicolumn{2}{l|}{ ref: Building 65 } & building 60 \\
\cline { 2 - 5 } & kBtu/sf/y & $\%$ of total & kBtu/sf/y & $\%$ of total \\
\hline Electric Base load & 21.6 & $18.0 \%$ & 4.9 & $3.8 \%$ \\
Heating fans, pumps & 5.9 & $4.9 \%$ & 7.7 & $6.0 \%$ \\
Gas Base load & 0.5 & $0.4 \%$ & 0.5 & $0.4 \%$ \\
Space Cooling & 13.9 & $11.5 \%$ & 12.3 & $9.6 \%$ \\
Space Heating & 78.3 & $65.2 \%$ & 102.6 & $80.2 \%$ \\
Total & 120.1 & $100.0 \%$ & 128.0 & $100.0 \%$
\end{tabular}


This project within the range of comparable projects
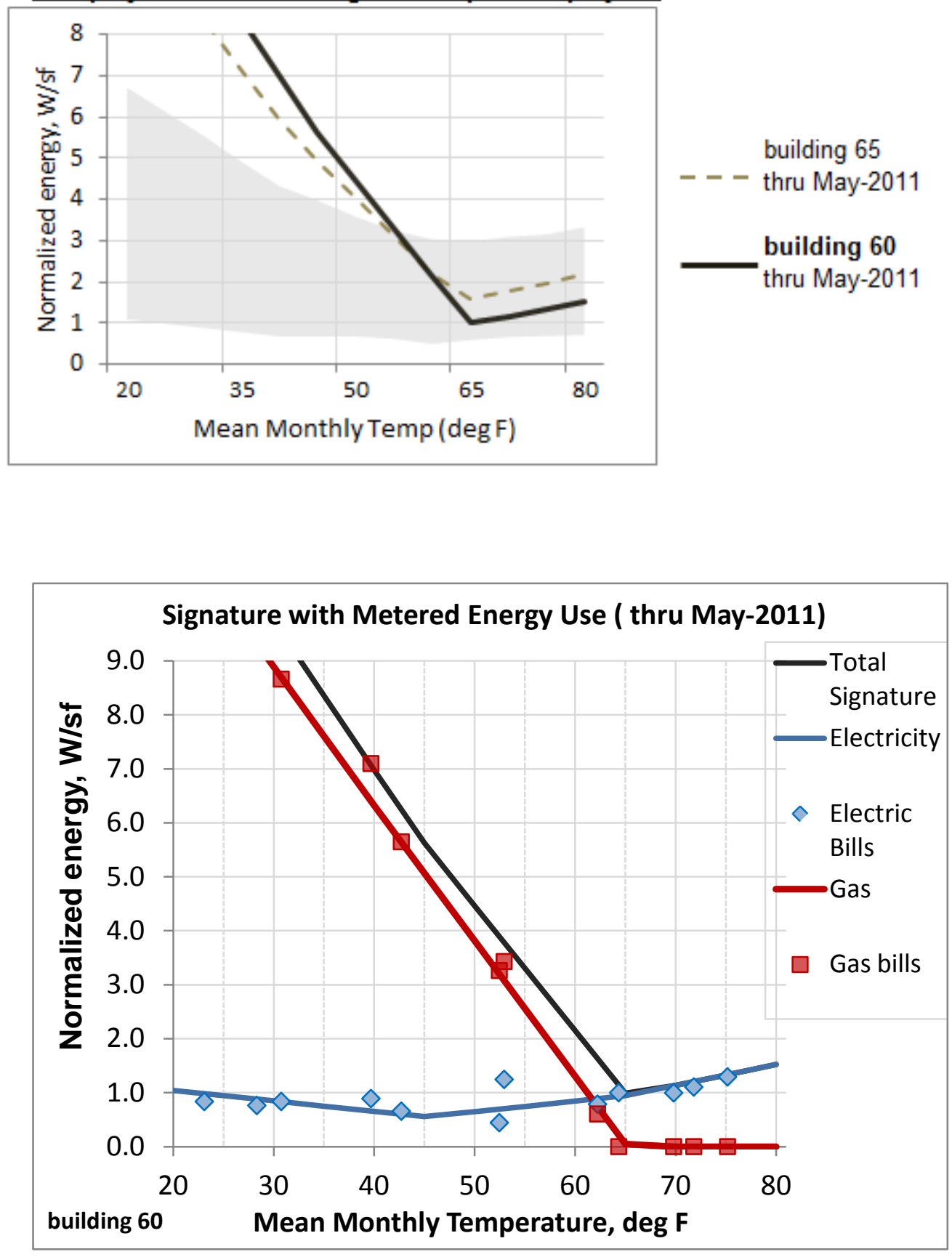


\section{Building 67}

Low electric base load could be consistent with a storage facility. Still high heat use, as with the other buildings.

From previous winter data, note the big drop in heating energy PY to CY. Found and closed an air leak? Other ventilation changes?

\begin{tabular}{ll}
\hline $\begin{array}{l}\text { Electric base load } \\
\text { Overall gas use }\end{array}$ & $\begin{array}{l}\text { Signature Observations } \\
\text { Leating impact of shell } \\
\text { and ventilation }\end{array}$ \\
$\begin{array}{l}\text { Gas base load } \\
\text { Vory high gas heat use } \\
\text { High temperature sensitivity of shell/ventilation }\end{array}$ \\
$\begin{array}{l}\text { Reheat } \\
\text { HVAC fan/pump use }\end{array}$ & Very good cooling efficiency \\
Data consistency & No apparent excessive reheat \\
\hline
\end{tabular}

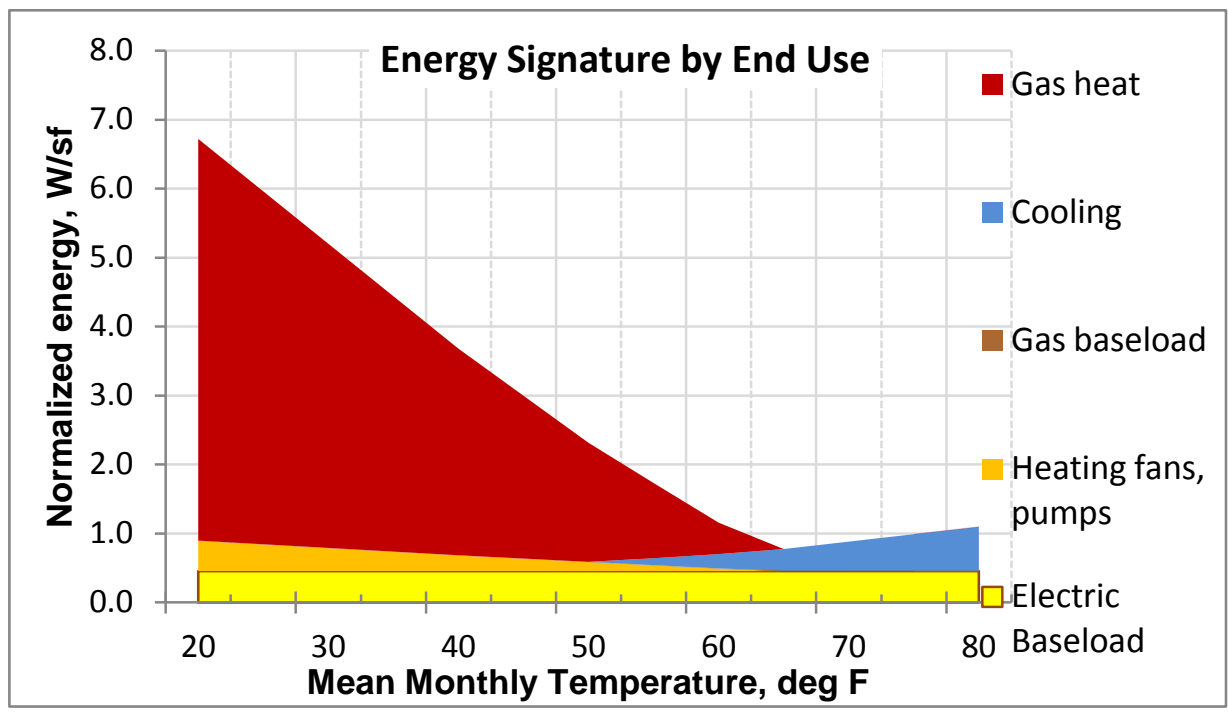



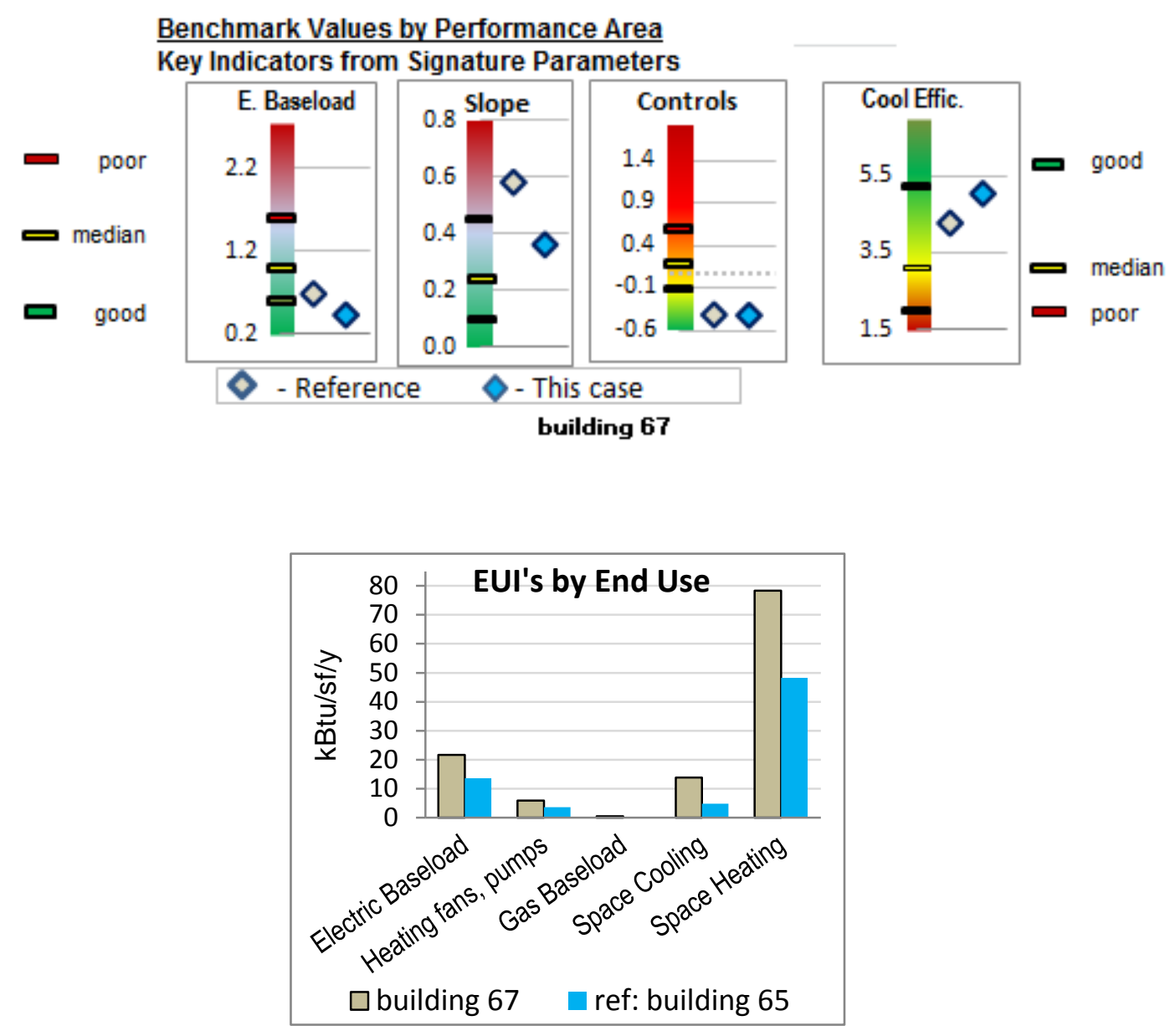

\begin{tabular}{lll|ll} 
& \multicolumn{2}{l}{ ref: Building 65} & \multicolumn{2}{l}{ building 67} \\
\cline { 2 - 5 } & kBtu/sf/y & $\begin{array}{l}\text { \% of } \\
\text { total }\end{array}$ & kBtu/sf/y & \% of total \\
\hline Electric Base load & 21.6 & $18.0 \%$ & 13.6 & $19.3 \%$ \\
Heating fans, pumps & 5.9 & $4.9 \%$ & 3.6 & $5.1 \%$ \\
Gas Base load & 0.5 & $0.4 \%$ & 0.2 & $0.2 \%$ \\
Space Cooling & 13.9 & $11.5 \%$ & 4.8 & $6.8 \%$ \\
Space Heating & 78.3 & $65.2 \%$ & 48.2 & $68.5 \%$ \\
Total & 120.1 & $100.0 \%$ & 70.5 & $100.0 \%$
\end{tabular}


This project within the ranqe of comparable projects
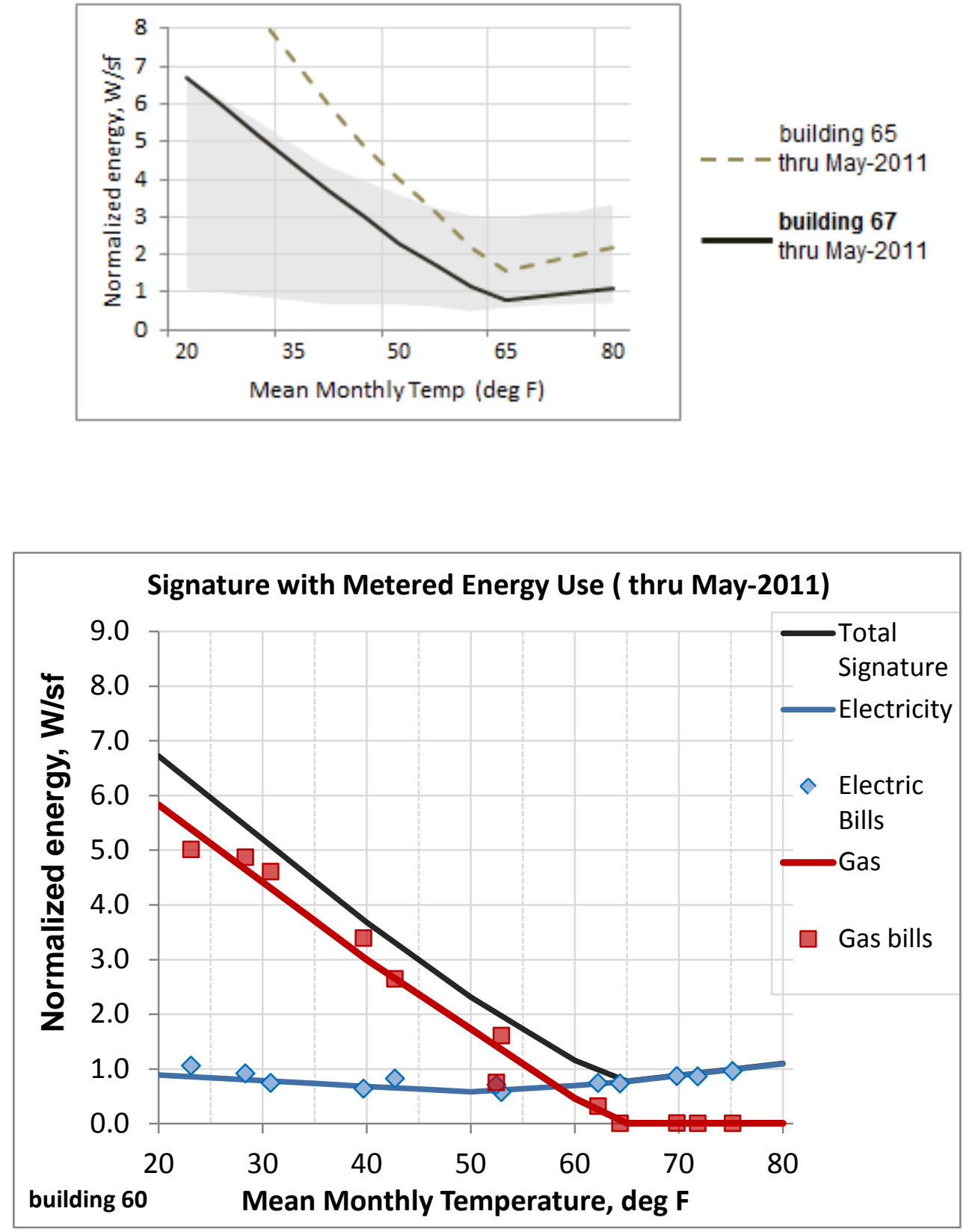


\section{Building 92}

High heating is similar to the other buildings. Again, may be partly related to running fans $24 \times 7$. Unusually high cooling energy. J ust a couple of months with cooling equipment problems? See early summer 2010 points in billing data; lab equipment electricity use that was high in those months.

\begin{tabular}{ll}
\hline & Signature Observations \\
Electric base load & Low electric base load \\
Overall gas use & Very high gas heat use \\
Heating impact of shell & High temperature sensitivity of shell/ventilation \\
and ventilation & \\
Gas base load & No excess gas use apparent from circulation/standby loss or reheat \\
Cooling efficiency & Very good cooling efficiency \\
Reheat & No apparent excessive reheat \\
HVAC fan/pump use & No apparent excessive energy use by systems fans/pumps \\
Data consistency & Orderly monthly performance \\
\hline
\end{tabular}

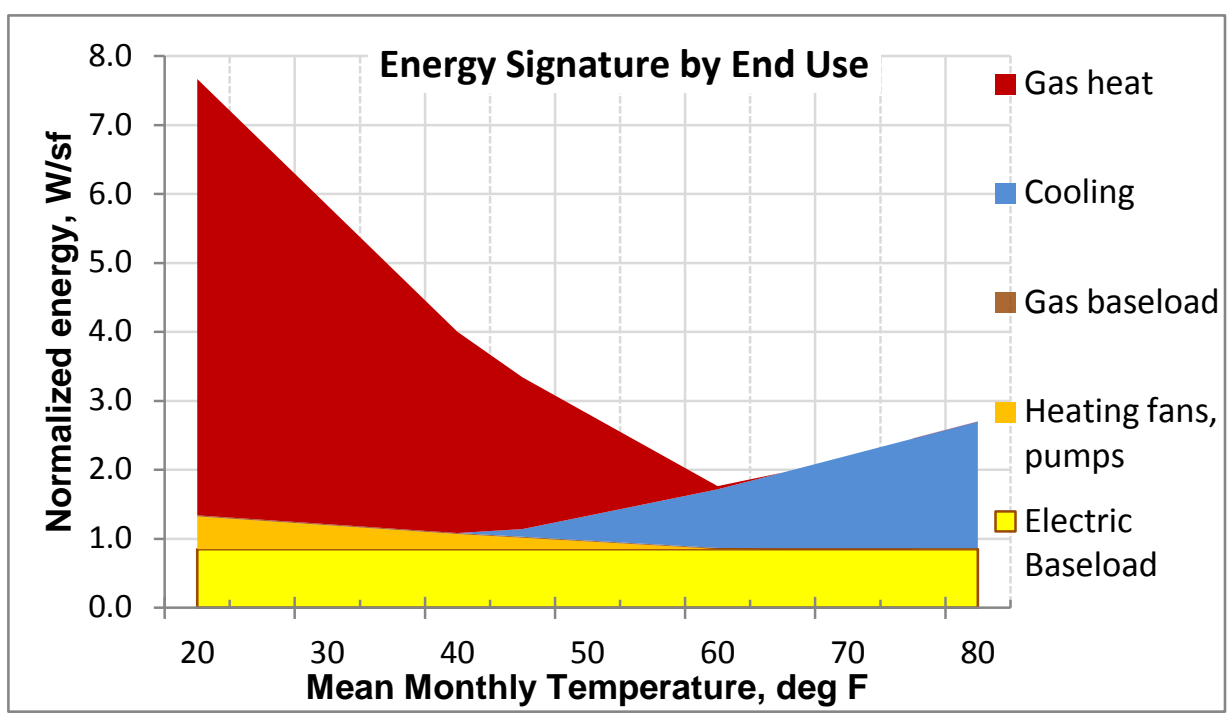



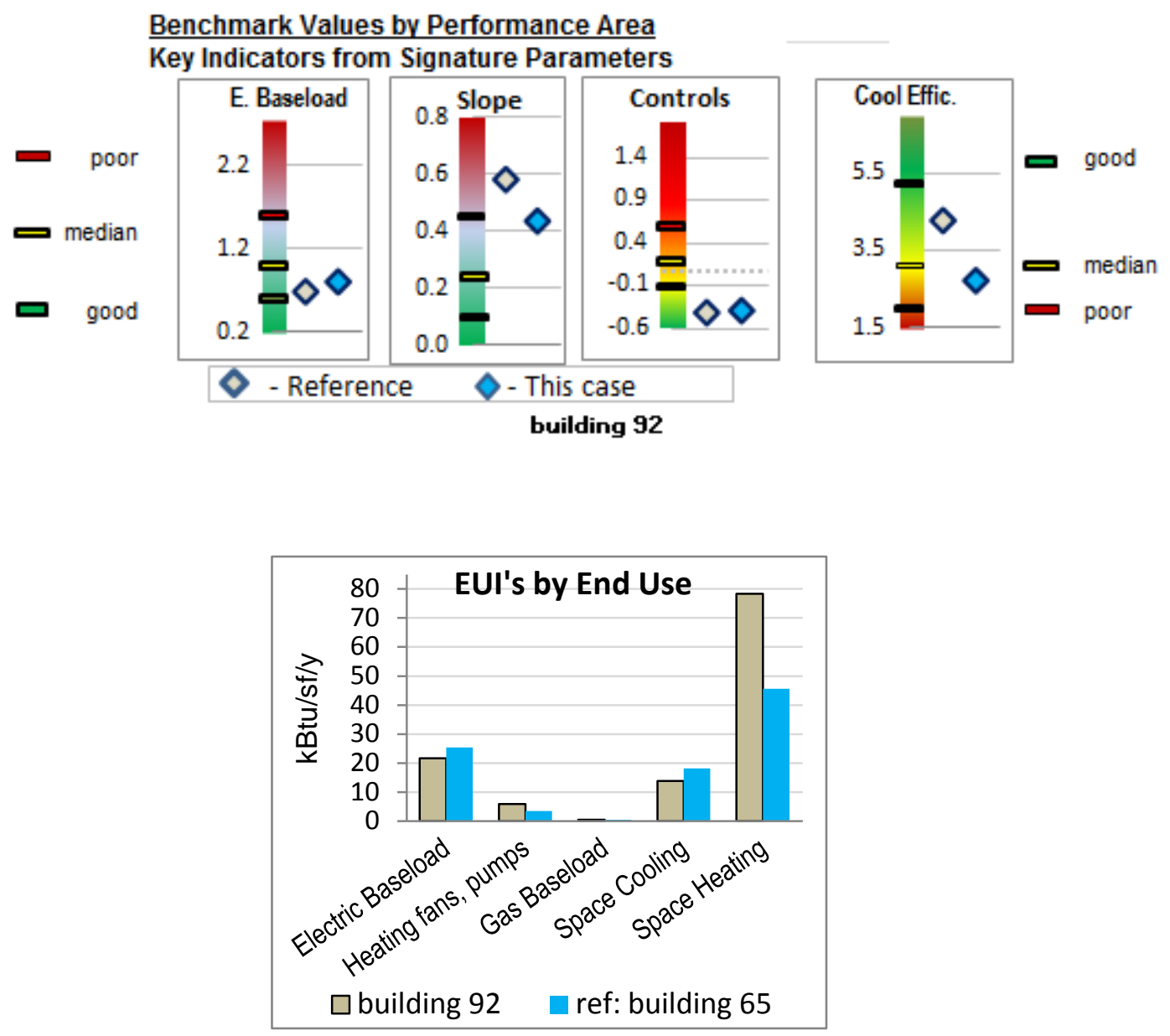

\begin{tabular}{lll|ll} 
& \multicolumn{2}{l|}{ ref: Building 65 } & building 92 \\
\cline { 2 - 5 } & kBtu/sf/y & $\begin{array}{l}\text { \% of } \\
\text { total }\end{array}$ & kBtu/sf/y & \% of total \\
\hline Electric Base load & 21.6 & $18.0 \%$ & 25.4 & $27.3 \%$ \\
Heating fans, pumps & 5.9 & $4.9 \%$ & 3.4 & $3.7 \%$ \\
Gas Base load & 0.5 & $0.4 \%$ & 0.5 & $0.5 \%$ \\
Space Cooling & 13.9 & $11.5 \%$ & 18.2 & $19.6 \%$ \\
Space Heating & 78.3 & $65.2 \%$ & 45.6 & $49.0 \%$ \\
Total & 120.1 & $100.0 \%$ & 93.0 & $100.0 \%$
\end{tabular}


This project within the ranqe of comparable projects
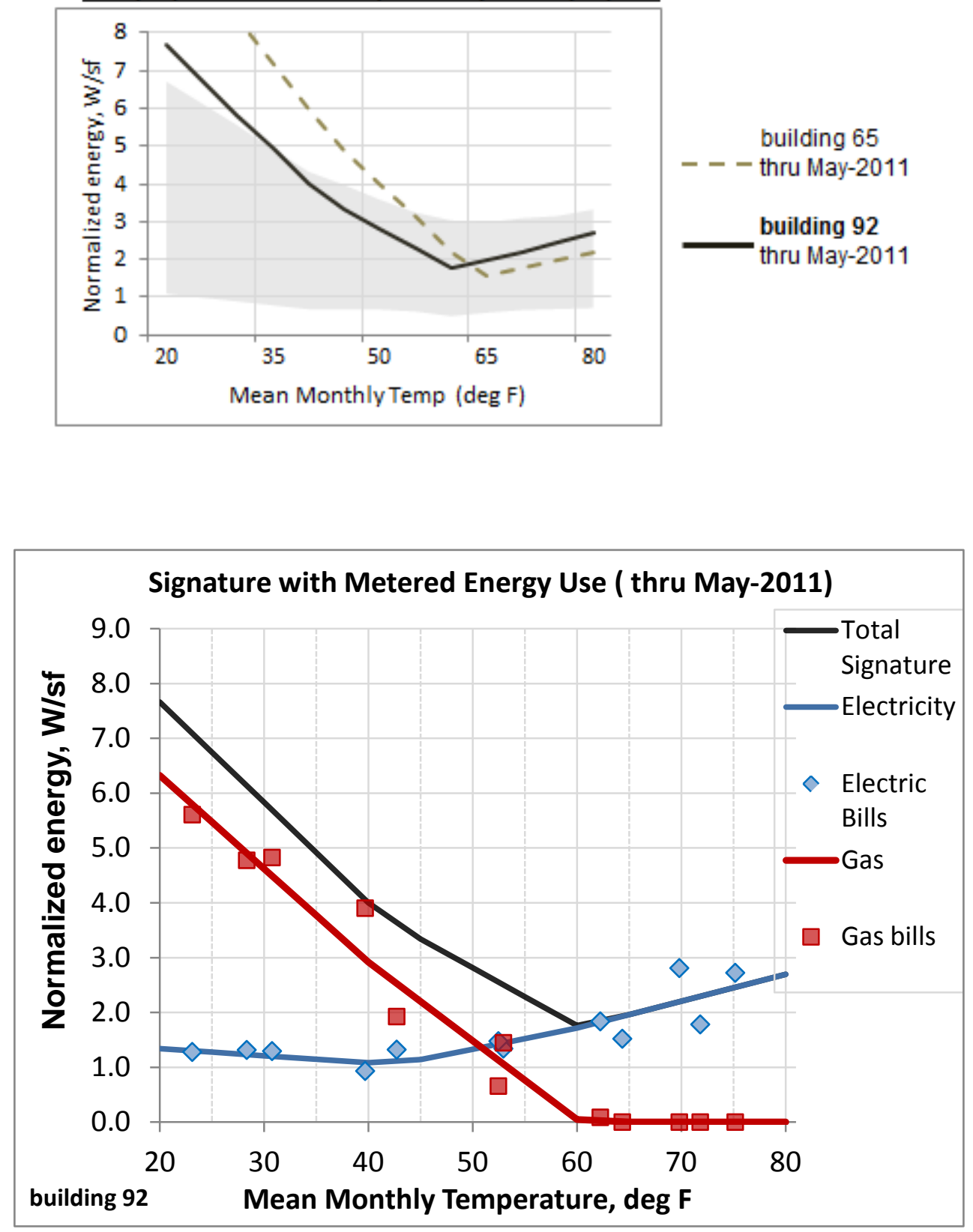


\section{Building 94}

Heat use high, but not as extreme as at the other locations.

Electricity shows much higher use early 2010 than for comparable temperatures at the end of 2010.

\begin{tabular}{ll}
\hline & Signature Observations \\
Electric base load & High electric base load \\
Overall gas use & Typical gas use \\
Heating impact of shell & No excess gas use apparent from shell/ventilation characteristics \\
and ventilation & \\
Gas base load & No excess gas use apparent from circulation/standby loss or reheat \\
Cooling efficiency & Very good cooling efficiency \\
Reheat & No apparent excessive reheat \\
HVAC fan/pump use & $\begin{array}{l}\text { Possible high energy use by systems fans/pumps or electric process } \\
\text { load }\end{array}$ \\
Data consistency & Orderly monthly performance \\
\hline
\end{tabular}

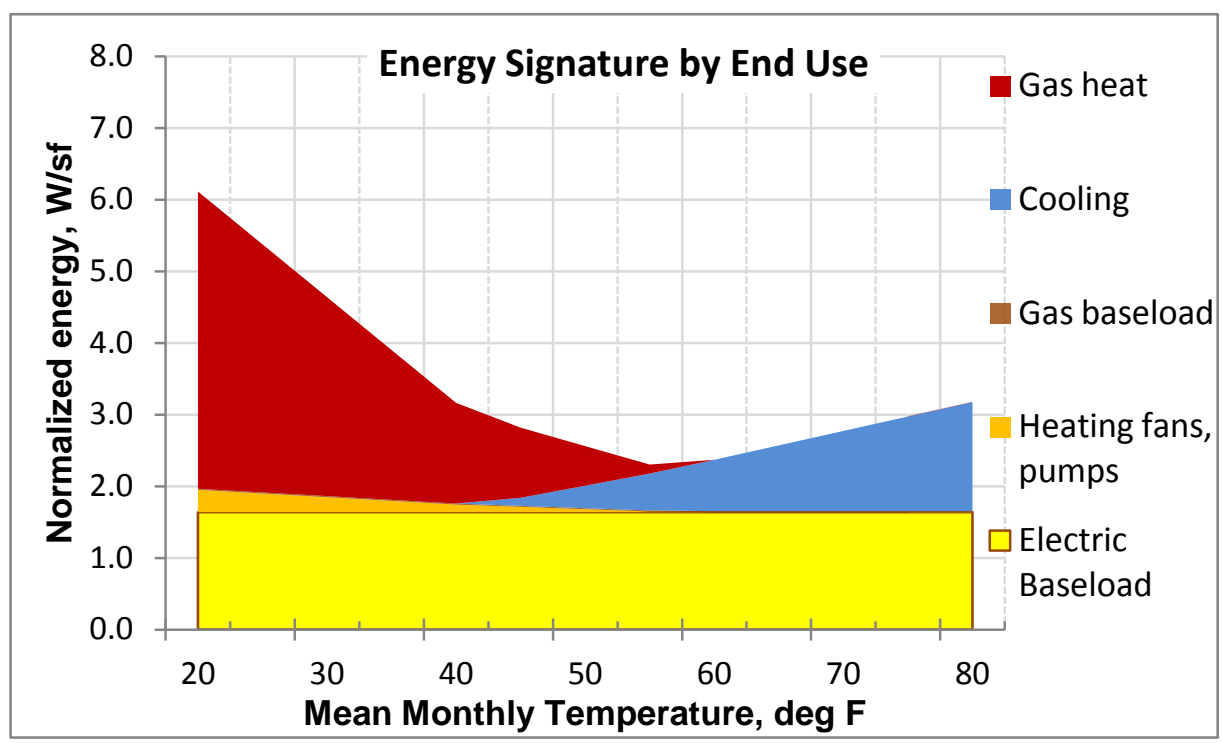



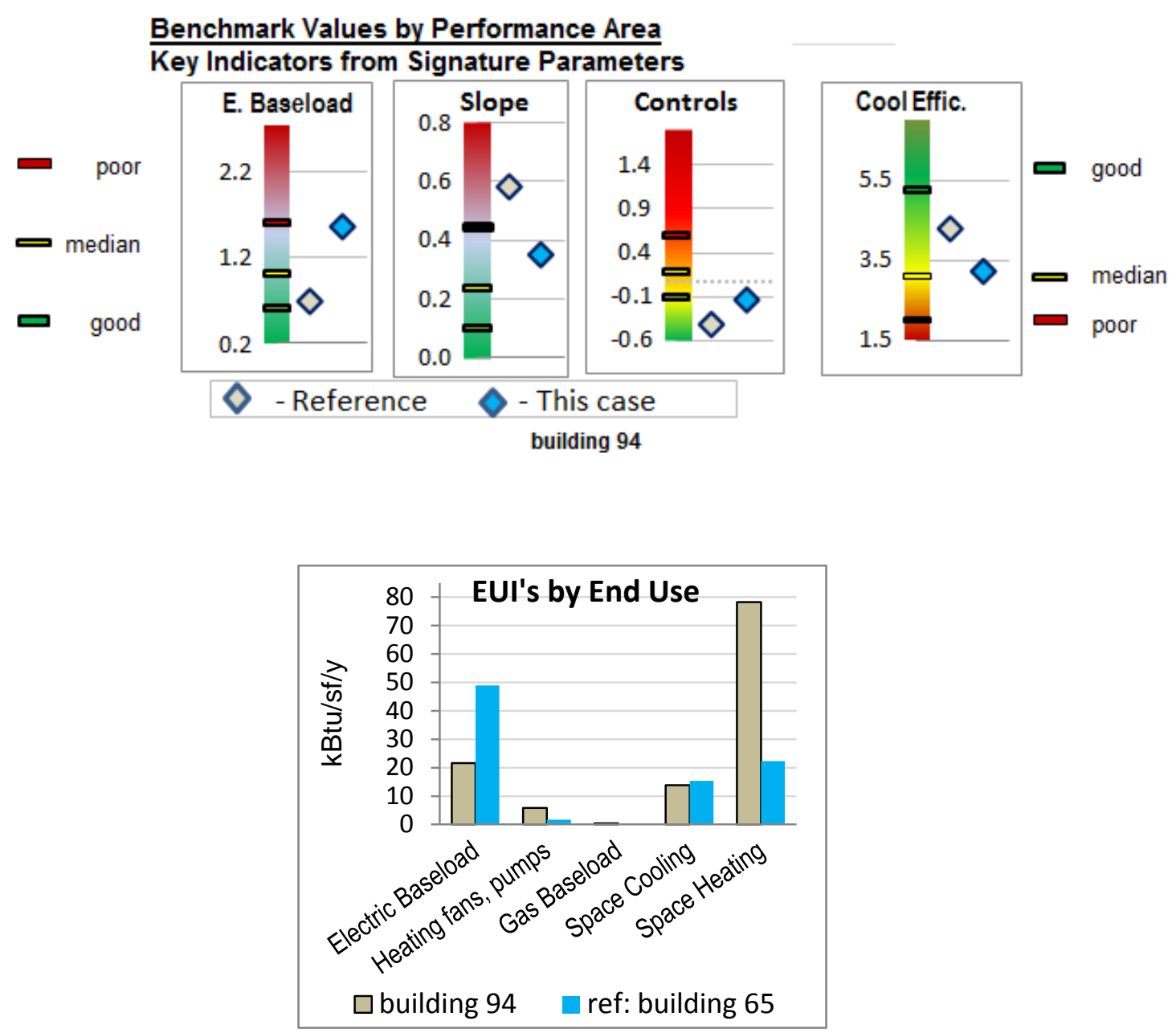
This project within the range of comparable projects
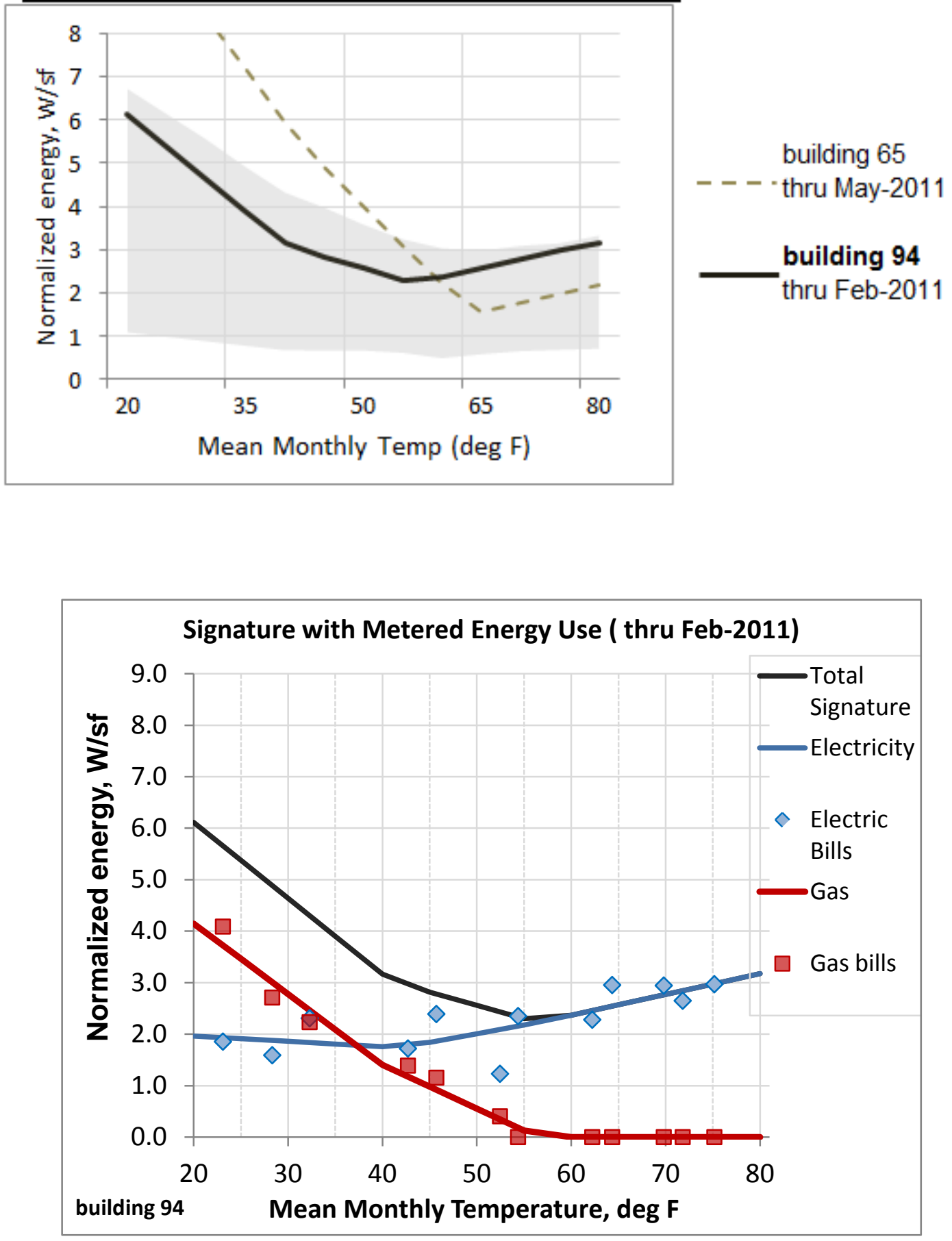


\section{Building 3323}

Commissaries/ supermarkets could have further First View refinements, possibly including:

- initial starting points of solution variables

- calculation changes to reflect direct export of refrigeration waste heat.

- appearance of "reheat" from open cases, cooling more space.

Still a basic useful level of information from this view. Combination of very high base load and high heat level shows failure to recapture waste heat in the winter. Conspicuous savings opportunity. "Controls effectiveness" problem flagged here is probably at least in part from things like open refrigeration cases.

\begin{tabular}{ll}
\hline Electric base load & $\begin{array}{l}\text { Signature Observations } \\
\text { Overall gas use }\end{array}$ \\
$\begin{array}{l}\text { Heating impact of shell } \\
\text { and ventilation }\end{array}$ & $\begin{array}{l}\text { Moderately high gas use } \\
\text { Gas base load }\end{array}$ \\
Cooling efficiency & No excess gas use apparent from circulation/standby loss or reheat \\
Reheat & Very good cooling efficiency \\
HVAC fan/pump use & Probable excessive reheat \\
Data consistency & High energy use by systems fans/pumps or electric process load \\
\hline
\end{tabular}

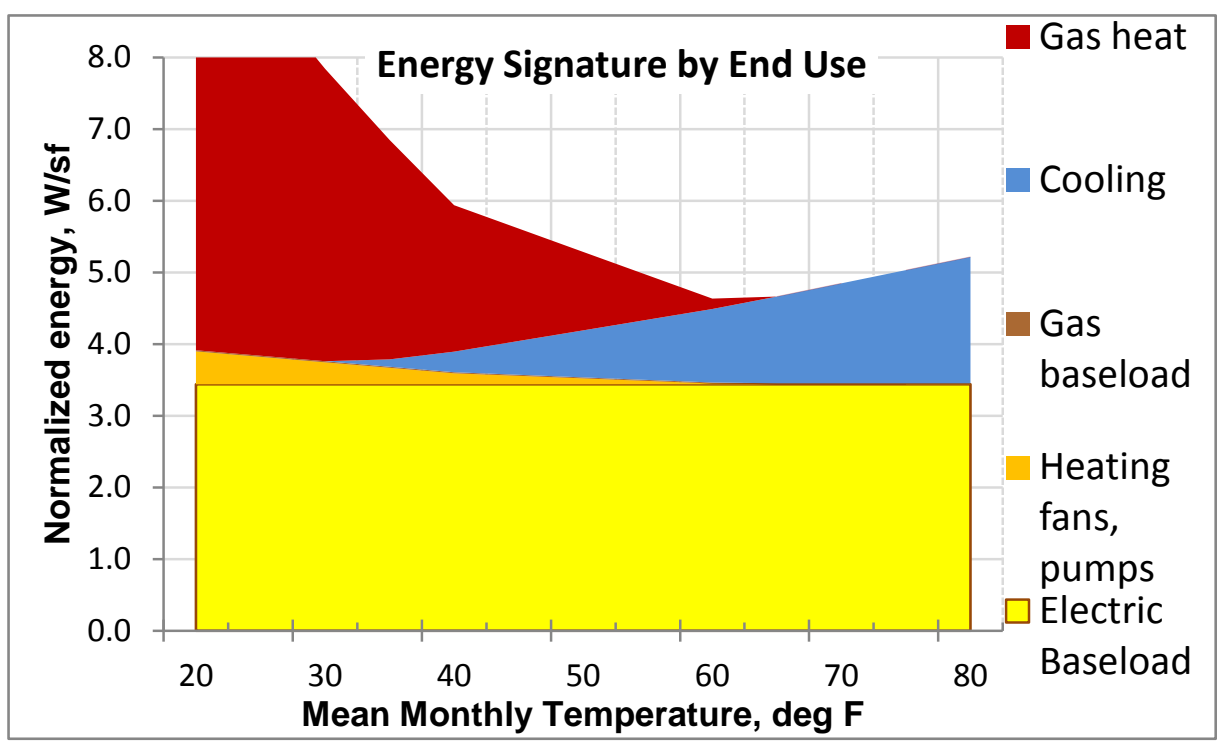



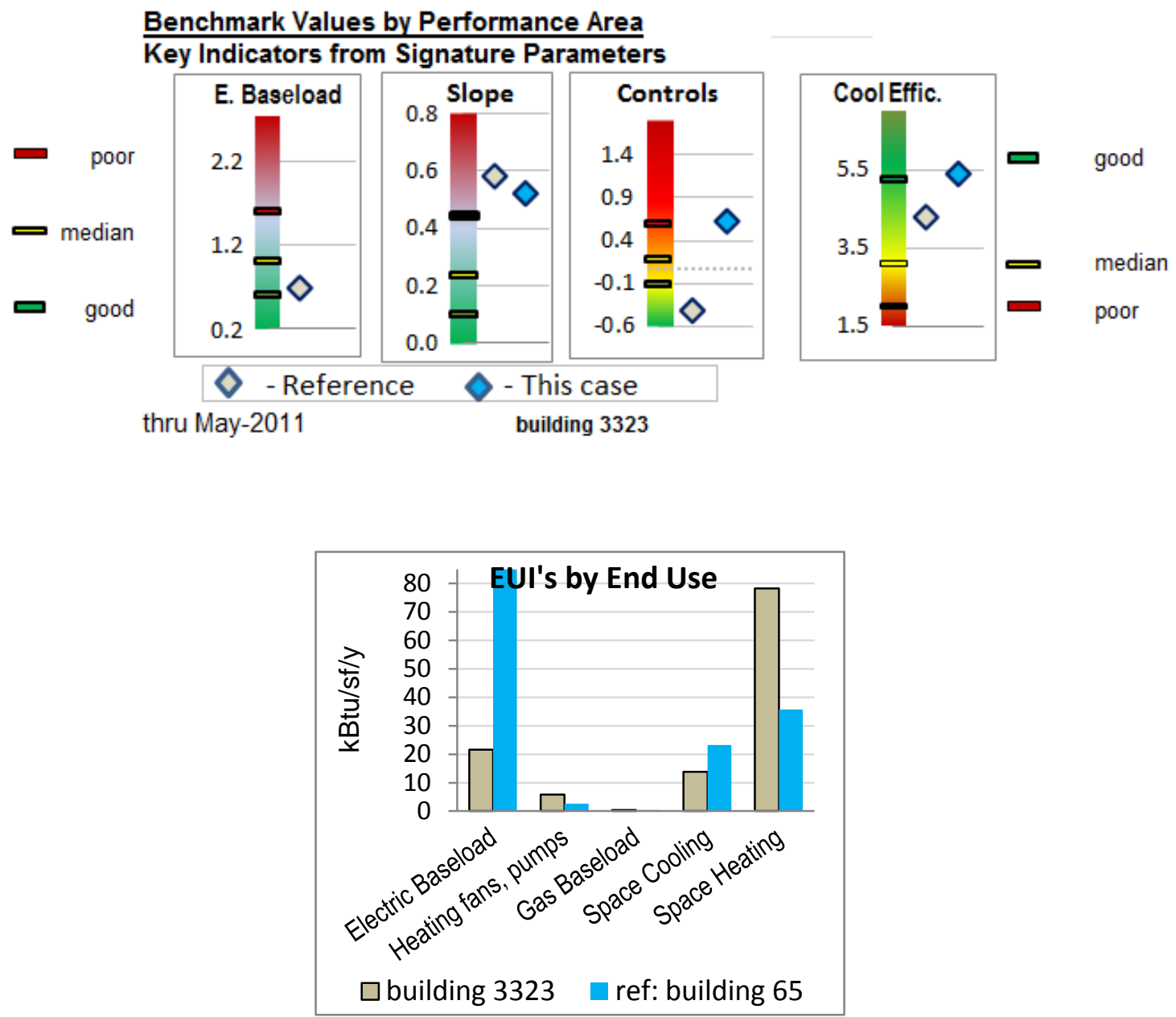

This project within the range of comparable projects

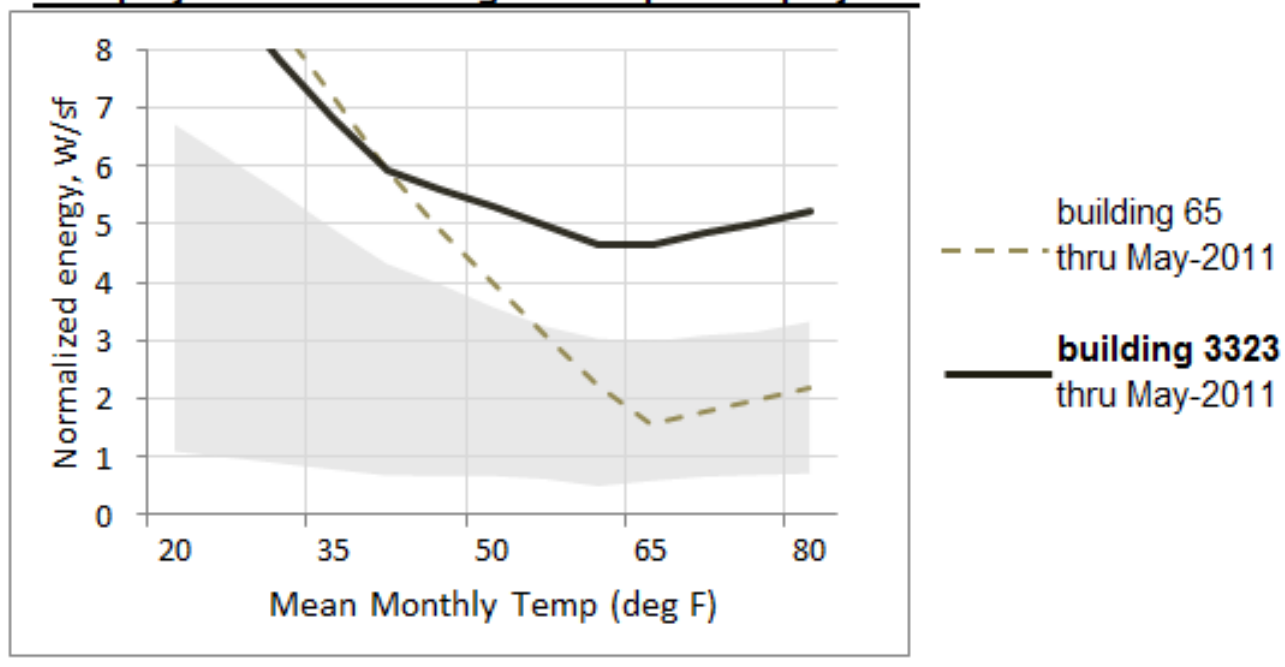




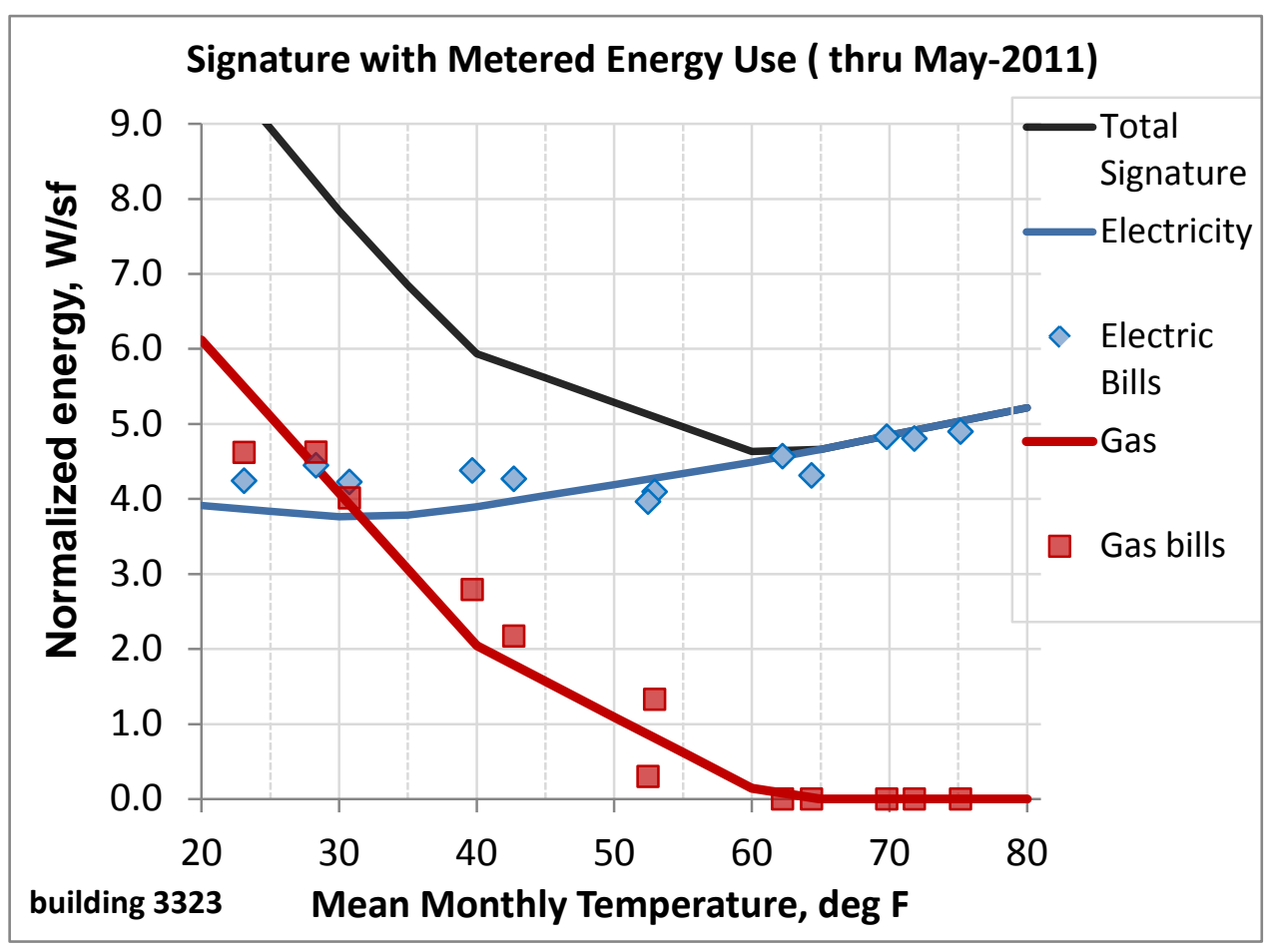




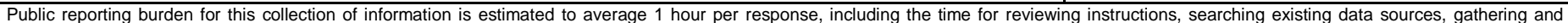

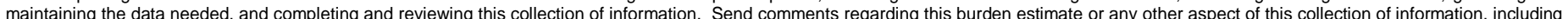

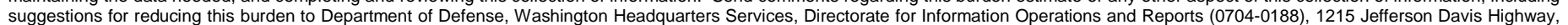

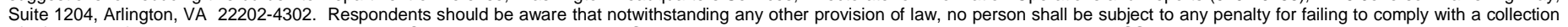
of information if it does not display a currently valid OMB control number. PLEASE DO NOT RETURN YOUR FORM TO THE ABOVE ADDRESS.

1. REPORT DATE (DD-MM-YYYY) 1 2. REPORT TYPE

December 2012 Final

\section{TITLE AND SUBTITLE}

Demonstration of a Rapid Energy Audit Procedure for use with an Army Sustainment Management System (SMS)

6. AUTHOR(S)

Joseph E. Karbarz and Michael N. Grussing

3. DATES COVERED (From - To)

\section{5a. CONTRACT NUMBER}

5b. GRANT NUMBER

5c. PROGRAM ELEMENT NUMBER

ITTP

5d. PROJECT NUMBER

FY11-41

5e. TASK NUMBER

5f. WORK UNIT NUMBER

7. PERFORMING ORGANIZATION NAME(S) AND ADDRESS(ES)

US Army Engineer Research and Development Center

Construction Engineering Research Laboratory

P.O. Box 9005

Champaign, IL 61826-9005

8. PERFORMING ORGANIZATION REPORT NUMBER

ERDC TR-12-14

\section{SPONSORING I MONITORING AGENCY NAME(S) AND ADDRESS(ES)}

Office of the Assistant Chief of Staff for Installation Management (ACSIM)

Facilities Branch (DAIM-ODF)

2511 Jefferson Davis Highway

Arlington, VA 22202
10. SPONSOR/MONITOR'S ACRONYM(S) ACSIM

11. SPONSOR/MONITOR'S REPORT NUMBER(S)

\section{DISTRIBUTION / AVAILABILITY STATEMENT}

Approved for public release; distribution is unlimited.

\section{SUPPLEMENTARY NOTES}

\section{ABSTRACT}

This report describes the demonstration of a rapid, whole-building energy performance assessment method to efficiently identify buildings for energy-conservation retrofits. The patent-pending process, called First View, can generate an energy signature or model that represents a sample building's energy performance. The only input data required are building type, square footage, monthly average temperatures, and gas and electric consumption for 12 consecutive months. Seven office buildings were assessed at Picatinny Arsenal, NJ. The analysis was performed manually using Microsoft Excel spreadsheet functions to produce summary output, reference charts, graphs, and tables. The First View model performed well across the sample building population. The energy signatures and associated output aligned well with field observations and local knowledge of the buildings under study.

This effort also included a more general effort to the study of total life-cycle cost analysis of facility condition in relation to energy performance. In this connection the authors provide a design for a comprehensive information dashboard report to provide information that could be used to expediently identify facilities that are good candidates for in-depth energy analysis.

\section{SUBJECT TERMS}

BUILDER Sustainment Management System (SMS), energy conservation, facility management, life-cycle costs, assessment, retrofit, Picatinny Arsenal, NJ

\section{SECURITY CLASSIFICATION OF:}

\section{a. REPORT}

Unclassified

\section{b. ABSTRACT}

Unclassified

\section{c. THIS PAGE}

Unclassified
17. LIMITATION OF ABSTRACT

\section{NUMBER} OF PAGES

45

\section{9a. NAME OF RESPONSIBLE} PERSON

19b. TELEPHONE NUMBER (include area code) 